Article

\title{
Cyclic Oxidation of High Mo, Reduced Density Superalloys
}

\author{
James L. Smialek *, Anita Garg, Timothy P. Gabb and Rebecca A. MacKay ${ }^{\dagger}$ \\ NASA Glenn Research Center, 21000 Brookpark, Cleveland, OH, 44135 USA; \\ E-Mails: anita.garg-1@ @asa.gov (A.G.); timothy.p.gabb@ nasa.gov (T.P.G.); \\ rmackay4462@wowway.com (R.A.M.) \\ $\dagger$ Retired from NASA Glenn Research Center. \\ * Author to whom correspondence should be addressed; E-Mail: james.1.smialek@ nasa.gov; \\ Tel.: +1-216-433-5500; Fax: +1-216-433-5544.
}

Academic Editor: Johan Moverare

Received: 31 October 2015 / Accepted: 18 November 2015 / Published: 24 November 2015

\begin{abstract}
Cyclic oxidation was characterized as part of a statistically designed, 12-alloy compositional study of 2 nd generation single crystal superalloys as part of a broader study to co-optimize density, creep strength, and cyclic oxidation. The primary modification was a replacement of $5 \mathrm{wt}$. $\% \mathrm{~W}$ by $7 \%$ or $12 \%$ Mo for density reductions of $2 \%-7 \%$. Compositions at two levels of $\mathrm{Mo}, \mathrm{Cr}, \mathrm{Co}$, and Re were produced, along with a midpoint composition. Initially, polycrystalline vacuum induction samples were screened in $1100{ }^{\circ} \mathrm{C}$ cyclic furnace tests using $1 \mathrm{~h}$ cycles for $200 \mathrm{~h}$. The behavior was primarily delimited by $\mathrm{Cr}$ content, producing final weight changes of $-40 \mathrm{mg} / \mathrm{cm}^{2}$ to $-10 \mathrm{mg} / \mathrm{cm}^{2}$ for $0 \% \mathrm{Cr}$ alloys and $-2 \mathrm{mg} / \mathrm{cm}^{2}$ to $+1 \mathrm{mg} / \mathrm{cm}^{2}$ for $5 \% \mathrm{Cr}$ alloys. Accordingly, a multiple linear regression fit yielded an equation showing a strong positive $\mathrm{Cr}$ effect and lesser negative effects of Co and Mo. The results for $5 \% \mathrm{Cr}$ alloys compare well to $-1 \mathrm{mg} / \mathrm{cm}^{2}$, and $+0.5 \mathrm{mg} / \mathrm{cm}^{2}$ for Rene' N4 and Rene' N5 (or Rene' N6), respectively. Scale phases commonly identified were $\mathrm{Al}_{2} \mathrm{O}_{3}, \mathrm{NiAl}_{2} \mathrm{O}_{4}, \mathrm{NiTa}_{2} \mathrm{O}_{6}$, and $\mathrm{NiO}$, with $(\mathrm{Ni}, \mathrm{Co}) \mathrm{MoO}_{4}$ found only on the least resistant alloys having $0 \% \mathrm{Cr}$ and $12 \% \mathrm{Mo}$. Scale microstructures were complex and reflected variations in the regional spallation history. Large faceted $\mathrm{NiO}$ grains and fine $\mathrm{NiTa}_{2} \mathrm{O}_{6}$ particles distributed along $\mathrm{NiAl}_{2} \mathrm{O}_{4}$ grain boundaries were typical distinctive features. $\mathrm{NiMoO}_{4}$ formation, decomposition, and volatility occurred for a few high Mo compositions. A creep, density, phase stability, and oxidation balanced $5 \% \mathrm{Cr}, 10 \% \mathrm{Co}, 7 \% \mathrm{Mo}$, and $3 \% \mathrm{Re}$ alloy was selected to be taken forward for more extensive evaluations in single crystal form.
\end{abstract}


Keywords: superalloys; oxidation; density; molybdenum content; single crystals

\section{Introduction}

The cyclic oxidation of superalloys has been an active topic for many decades of research in high temperature materials. It is not the intent of the present study to revisit the many nuances that arise for various specific alloys; the general compositional trends of conventional alloys can be surmised from reviews [1,2]. In the broadest sense, Ni-base superalloys can be divided into $\mathrm{Al}_{2} \mathrm{O}_{3}$ and $\mathrm{Cr}_{2} \mathrm{O}_{3}$-formers, though other oxides will indeed be present. In this discussion and paper, all alloy compositions will be expressed in weight percent. At $1100^{\circ} \mathrm{C}$, cyclic oxidation performance will generally separate commercial alloys into these two groups, with most $\mathrm{Al}_{2} \mathrm{O}_{3}$-formers exceeding the performance of $\mathrm{Cr}_{2} \mathrm{O}_{3}$-formers [2] (In fact, the groups can be roughly separated as high $\geq 5 \% \mathrm{Al}$, low $\leq 15 \% \mathrm{Cr}$ and the inverse, all wt. \% in this paper). Alumina-forming alloys excel over chromia-formers because of slower oxidation rates and corresponding reductions in spallation. While $\mathrm{Al}$ contents $\geq 6 \%$ are preferred for optimum behavior, some level of $\mathrm{Cr}$, also $\geq 6 \%$, is required to assist $\mathrm{Al}$ in the formation of a continuous rate controlling layer. Some transient oxidation always occurs and takes form as $\mathrm{NiAl}_{2} \mathrm{O}_{4}$ and $\mathrm{NiCr}_{2} \mathrm{O}_{4}$ spinels (or some solid solution thereof). These are not too detrimental provided they are effective before rapid $\mathrm{NiO}$ growth is allowed to proceed. Other alloying additions result in a variety of complex scale mixtures and variable performance. In general, it can be said that some $\mathrm{Cr}$ and $\mathrm{Ta}$ are beneficial in $\mathrm{Al}_{2} \mathrm{O}_{3}$-forming alloys, while $\mathrm{Ti}, \mathrm{Nb}$, and $\mathrm{W}$ are detrimental. Mo in moderation $(\leq 10 \%)$ has not been identified with a strong beneficial or detrimental trend. $\mathrm{NiTa}_{2} \mathrm{O}_{6}$ tri-rutiles are generally associated with better performance, possibly because they assist in tying up $\mathrm{Ni}$ in dispersed, slowly growing fine particles. On the other hand, Ti, Mo, and $\mathrm{W}$ alloying additions can be manifested in fast growing, non-protective $\mathrm{TiO}_{2}, \mathrm{NiTiO}_{3}$, and $\mathrm{Ni}(\mathrm{Mo}, \mathrm{W}) \mathrm{O}_{4}$ phases, leading to rapid mass loss. Overall, the optimum performance is obtained with minimal $\mathrm{NiAl}_{2} \mathrm{O}_{4}$ transient spinel and a stable continuous $\alpha-\mathrm{Al}_{2} \mathrm{O}_{3}$ layer growing under the spinel layer.

Alloy development has progressed well-enough to produce second generation single crystal superalloys that are also highly oxidation resistant, including CMSX-4, Rene' N5, PWA 1484, SC180, RR2000, and TMS-82. While co-optimization was the primary focus of this study, there are some engineering and mechanistic oxidation aspects that can first be briefly reviewed for context. Most aero-engine single crystal alloys contain greater than $5 \% \mathrm{Al}$ and less than $10 \% \mathrm{Cr}$, centered near $\mathrm{Ni}-10 \mathrm{Co}-6 \mathrm{Al}-8 \mathrm{Cr}-8 \mathrm{Ta}-$ $6 \mathrm{~W}-2 \mathrm{Mo}-0 \mathrm{Ti}-0 \mathrm{Nb}$ (wt. \%). By comparison, one of the best performing conventional alloys, B1900, consists of $\mathrm{Ni}-10 \mathrm{Co}-6 \mathrm{Al}-8 \mathrm{Cr}-4.3 \mathrm{Ta}-0.1 \mathrm{~W}-6 \mathrm{Mo}-1 \mathrm{Ti}-0.1 \mathrm{Nb}$ [2]. Now small levels of $\mathrm{Hf}, \mathrm{Y}, \mathrm{C}, \mathrm{B}$ are included in single crystals with special attention to minimize or eliminate small ppm levels of a detrimental sulfur impurity. Thus 2 nd generation single crystals have a great propensity for $\mathrm{Al}_{2} \mathrm{O}_{3}$ formation and provide some of the best cyclic oxidation performance of all commercial superalloys. While mechanistic details may abound, it can often be reduced to a preferred sequence of minimal $\mathrm{Ni}(\mathrm{Al}, \mathrm{Cr})_{2} \mathrm{O}_{4}$ transient oxidation, followed by a rate-controlling $\mathrm{Al}_{2} \mathrm{O}_{3}$ healing layer, with concurrent, but apparently innocuous, fine particles of $\mathrm{NiTa}_{2} \mathrm{O}_{6}$ (tri-rutile) in the interfacial region of the transient-healing layers. Excursions to other scale phases, such as $\mathrm{NiO}, \mathrm{Cr}_{2} \mathrm{O}_{3}, \mathrm{NiTiO}_{3}, \mathrm{Ni}(\mathrm{Mo}, \mathrm{W}) \mathrm{O}_{4}$, are generally associated with non-protective behavior, internal or discontinuous $\mathrm{Al}_{2} \mathrm{O}_{3}$, and alloy compositions outside that preferred range. 
Numerous studies have characterized the oxidation behavior of these alloys. For example, the importance of S, C, Hf, and Y is discussed in [3-8]. Some unusual orientation effects were categorized by Yuan [9]. Complex transient $\mathrm{Ni}(\mathrm{Al}, \mathrm{Cr})_{2} \mathrm{O}_{4}$ spinel, and (Ti,Cr,Al)(Ti,Ta) $\mathrm{O}_{4}$ rutile, and $\mathrm{NiTa}_{2} \mathrm{O}_{6}$ tri-rutile were reported in addition to more common $\mathrm{NiO}$ and $\mathrm{Al}_{2} \mathrm{O}_{3}$ structures [10]. Elegant cross-sectional STEM characterizations have documented $\mathrm{Ta}, \mathrm{Hf}, \mathrm{Y}$, and $\mathrm{Zr}$ segregation at grain boundaries in the alumina scale formed at $1050-1150{ }^{\circ} \mathrm{C}$ on a Ni-6.1Al-7.3Cr-7.3Co- $4.9 \mathrm{~W}-6.5 \mathrm{Ta}-1.5 \mathrm{Mo}-2.9 \mathrm{Re}-0.15 \mathrm{Hf}-0.01 \mathrm{Zr}-$ 0.02Y 2nd generation single crystal superalloy, most closely resembling doped Rene' N5 [11]. The morphologies and transition from initial $\theta-\mathrm{Al}_{2} \mathrm{O}_{3}$ to steady-state $\alpha-\mathrm{Al}_{2} \mathrm{O}_{3}$ were also documented. Interestingly, no transient $\mathrm{Ni}(\mathrm{Al}, \mathrm{Cr})_{2} \mathrm{O}_{4}$ spinel or $\mathrm{NiTa}_{2} \mathrm{O}_{6}$ was reported.

The primary direction of the present research was to reduce the density of a new alloy compared to second generation single crystal superalloys (Rene' N5, PWA 1484, CMSX4, SC180, TMS-82, RR2000) for turbine blade applications, while maintaining other critical properties. This has significant implications for aero-turbines, where excess rotating airfoil weight cascades into large penalties (perhaps a multiplier as large as $10 \times$ ) for overall engine thrust-to-weight efficiencies. In that regard an earlier study had also focused on reducing density to $8.1 \mathrm{~g} / \mathrm{cm}^{3}-8.5 \mathrm{~g} / \mathrm{cm}^{3}$ and developed LEK 94 (Leichte Einkristalllegierung) with compositions near $\mathrm{Ni}-6.5 \mathrm{Al}-6.0 \mathrm{Cr}-7.5 \mathrm{Co}-3.5 \mathrm{~W}-2.5 \mathrm{Re}-2.3 \mathrm{Ta}-2.1 \mathrm{Mo}-1.0 \mathrm{Ti}$ and with creep properties approaching those of CMSX-4 [12,13]. Basically the lower W, Re, Ta contents achieved the lower density of this superalloy. Another study concurrent with the present program had located optimal design spaces based on fundamentals [14]. Here, co-optimized projected creep strength, alloy stability, density, cost, and castability have been considered for a vast array of potential alloys. An alloy composition was identified that embodied these attributes: $\mathrm{Ni}-4 \mathrm{Cr}-10 \mathrm{Co}-3 \mathrm{Re}-3 \mathrm{~W}-7 \mathrm{Al}-5 \mathrm{Ta}$. These prior studies did not address oxidation directly. Other more recent high $\mathrm{Cr}$, but lower $\mathrm{Al}$, single crystal alloys were developed (SCA425/STAL-15) to promote $\mathrm{Cr}_{2} \mathrm{O}_{3}$ scales for corrosion resistance in stationary gas turbines and helium reactors [15-17].

In the present program higher Mo contents have been explored while eliminating W. Mo is a powerful solid solution strengthener, but with a density much closer to Ni than other refractory strengthening elements, such as Re and W. According to the fundamental design study, Mo is about $3 \times$ the cost of W, but are both relatively inexpensive for refractory metals [14]. The diffusion coefficient predicted for $\mathrm{Ni}-\mathrm{Mo}$ alloys is only $2 \times$ that for $\mathrm{Ni}-\mathrm{W}$ alloys [14]. And the microstructural stability factor based on d-electron band theory is about the same for $\mathrm{Ni}-\mathrm{Mo}$ and $\mathrm{Ni}-\mathrm{W}$ alloys [14]. In the present work, an empirical Design of Experiments (DoE) approach was employed to minimize the number of alloys cast while extracting the maximum predictive capability of a multi-factor regression model, yet including several engineering-judgement alloys. The design employed D-optimal methodology in JMP software by SAS Institute Inc., Chehalis, WA, USA $[18,19]$.

The baseline alloy contained 6.1 wt. $\%$ Al, 6.2\% Ta, 0.01\% C and 50-100 ppm Y-doping, with selected variations in $\mathrm{Cr}$, Co, Mo, and Re levels, but no W. The Mo levels were relatively high at $7 \%$ and $12 \%$, (with $\mathrm{Cr}$ at $0 \%$ and 5\%; $\mathrm{Co}$ at $0 \%$ and $10 \%$, and $\mathrm{Re}$ at $0 \%$ and $3 \%$ ). The same alloys have also been screened for phase stability and density. Coupled with these oxidation studies, the $5 \mathrm{Cr}-10 \mathrm{Co}-7 \mathrm{Mo}-3 \mathrm{Re}$ (nominal wt. \%) alloy was selected as a most promising composition space and was taken along with limited other compositions for further studies as single crystals, doping with Hf, and more extensive oxidation/corrosion tests. Some oxidation and corrosion results were included in previous publications, along with density, phase stability, and creep resistance [20-22]. Ultimately, 
the composition range of greatest potential was targeted in an associated patent [23]. However the complete oxidation basis and compositional effects leading to these alloy choices had not been reported in detail. The purpose of this paper is to present the compositional oxidation effects from tests of polycrystalline samples leading to this optimized alloy design space. In that regard, since some alloys here contain the relatively high level of $12 \% \mathrm{Mo}$, some attention is given to the expected $\mathrm{NiMoO}_{4}$ scale phase as an indicator of declining oxidation performance.

\section{Experimental Section}

Experimental polycrystalline superalloy castings were produced by vacuum induction melting (VIM) into $1.3 \mathrm{~mm} \times 15 \mathrm{~mm}$ dia. cylindrical bars. The compositional matrix is given in Table 1, introducing a code (abcd), where 0 refers to the low value of the element in the design and 1 refers to the high value. As mentioned previously, the low $\mathrm{Cr}$, Co, Mo, Re values were 0, 0, 7, 0 wt. \% respectively, and would apply to the (0000) alloy. Conversely, the high $\mathrm{Cr}$, Co, Mo, Re values were 5, 10, 12, 3 wt. \% respectively, and would apply to a (1111) designation. Midlevel variations are given the designation " 5 ". (The two digit alloy prefix, when used, refer to casting sequence history, sometimes needed to distinguish preliminary versions of the same alloy). Material from a previous program (\# 143), with 6.1 Al, 6.2 Ta and 13.8 Mo (wt. \%), (no Cr, Co, or Re), was tested in fully heat treated single crystal (FHTSX) condition and included for comparison. The bars were sectioned into $\sim 2 \mathrm{~mm}$ disks and polished through 600 grit emery. They were cyclically oxidized in pre-oxidized $\mathrm{FeCrAl}(\mathrm{Zr})$ cups that were automatically lowered in a vertical tube furnace at $1100{ }^{\circ} \mathrm{C}$ for 2001 -h cycles. Each cooling cycle achieved $\sim 100{ }^{\circ} \mathrm{C}$ in $\sim 10$ min. Samples were weighed manually on an analytical balance at a graduated time frequency of $1 \mathrm{~h}, 2,5,10,20,40 \ldots 200 \mathrm{~h}$. A second weight was obtained at $100 \mathrm{~h}$ and $200 \mathrm{~h}$ to monitor delayed moisture-induced scale spallation (MIDS). Because of limited sample availability, TGA testing (Setaram, Caluire, France) for only one high Mo, low Cr, Co, Re alloy was performed, also at $1100{ }^{\circ} \mathrm{C}$. Scale appearance was recorded by optical macro/micro photography and for selected alloys by scanning electron microscopy (SEM, Hitachi, Tokyo, Japan), at $15 \mathrm{kV}$, on carbon coated samples. Scale phases were determined by X-ray diffractometer (XRD, Brüker, Karlsruhe, Germany) scans.

Table 1. Alloy designation, nominal chemistry, and ranked mass change after cyclic oxidation of 12 LDS alloys for regression model. (Base alloy contains 7 Mo, 6 Al, 6.2 Ta, 50-100 ppm Y, and $80-100 \mathrm{ppm} \mathrm{C}$ ).

\begin{tabular}{|c|c|c|c|c|c|c|}
\hline \multirow{2}{*}{ Rank } & \multicolumn{4}{|c|}{ Nominal, wt. \% } & \multirow{2}{*}{$\begin{array}{c}\text { Sample } \\
\text { Alloy Code }\end{array}$} & \multirow{2}{*}{$\begin{array}{l}\Delta W / A, \mathrm{mg} / \mathrm{cm}^{2} \\
1100{ }^{\circ} \mathrm{C}, 200 \mathrm{~h}\end{array}$} \\
\hline & $\mathrm{Cr}$ & Co & Mo & $\mathbf{R e}$ & & \\
\hline 1 & 5 & 0 & 7 & 0 & $63-1000$ & 0.752 \\
\hline 2 & 5 & 10 & 12 & 0 & $58-1110$ & -0.269 \\
\hline 3 & 5 & 10 & 7 & 0 & $57-1100$ & -0.478 \\
\hline 4 & 5 & 10 & 7 & 3 & $68-1101$ & -1.195 \\
\hline 5 & 5 & 0 & 12 & 3 & 94-1011 & -1.733 \\
\hline
\end{tabular}


Table 1. Cont.

\begin{tabular}{|c|c|c|c|c|c|c|}
\hline \multirow{2}{*}{ Rank } & \multicolumn{4}{|c|}{ Nominal, wt. \% } & \multirow{2}{*}{$\begin{array}{c}\text { Sample } \\
\text { Alloy Code }\end{array}$} & \multirow{2}{*}{$\frac{\Delta W / A, \mathrm{mg} / \mathrm{cm}^{2}}{1100{ }^{\circ} \mathrm{C}, 200 \mathrm{~h}}$} \\
\hline & $\mathrm{Cr}$ & Co & Mo & $\mathbf{R e}$ & & \\
\hline 6 & 2.5 & 5 & 9.5 & 1.5 & $75-5555$ & -4.495 \\
\hline 7 & 2.5 & 0 & 9.5 & 3 & $67-5051$ & -5.362 \\
\hline 8 & 0 & 0 & 7 & 0 & $61-0000$ & -9.719 \\
\hline 9 & 0 & 10 & 7 & 3 & $62-0101$ & -13.392 \\
\hline 10 & 0 & 0 & 12 & 0 & $64-0010$ & -20.114 \\
\hline 11 & 0 & 10 & 12 & 0 & $66-0110$ & -27.426 \\
\hline 12 & 0 & 10 & 12 & 0 & $95-0111$ & -41.441 \\
\hline
\end{tabular}

\section{Results}

\subsection{Mass Change}

The cyclic weight change results are shown in Figure 1. Cr was the design parameter that exerted the largest effect. Accordingly, Figure 1a groups the alloys that contained nominally $2.5 \%-5 \% \mathrm{Cr}$. The alloys with $5 \% \mathrm{Cr}$ (1bcd) were relatively oxidation resistant, showing modest mass gain, and some losses for the first $100 \mathrm{~h}$. It is seen that alloy (1000), with $5 \% \mathrm{Cr}, 0 \% \mathrm{Co}, 7 \% \mathrm{Mo}$, and $0 \% \mathrm{Re}$, maintained a positive mass change for the entire 200-h test. The other $5 \mathrm{Cr}$ alloys exhibited slight mass losses. After an extended exposure to ambient moisture at the 100-h mark, delayed interfacial spallation occurred (i.e., spalling to bare metal), resulting in an additional vertical drop in the curve for most alloys. This event produced a change in slope of the remainders of the curves due to re-oxidation of a freshly exposed metal surface and, possibly, a change in scale composition and kinetics. The additions of Co, Mo, and possibly Re, in various combinations, is seen to modestly affect oxidation resistance, giving a mass loss up to $\sim 2 \mathrm{mg} / \mathrm{cm}^{2}$. The alloys with $2.5 \% \mathrm{Cr}$, (5555 and 5051), show further degradation, losing $\sim 5 \mathrm{mg} / \mathrm{cm}^{2}$.
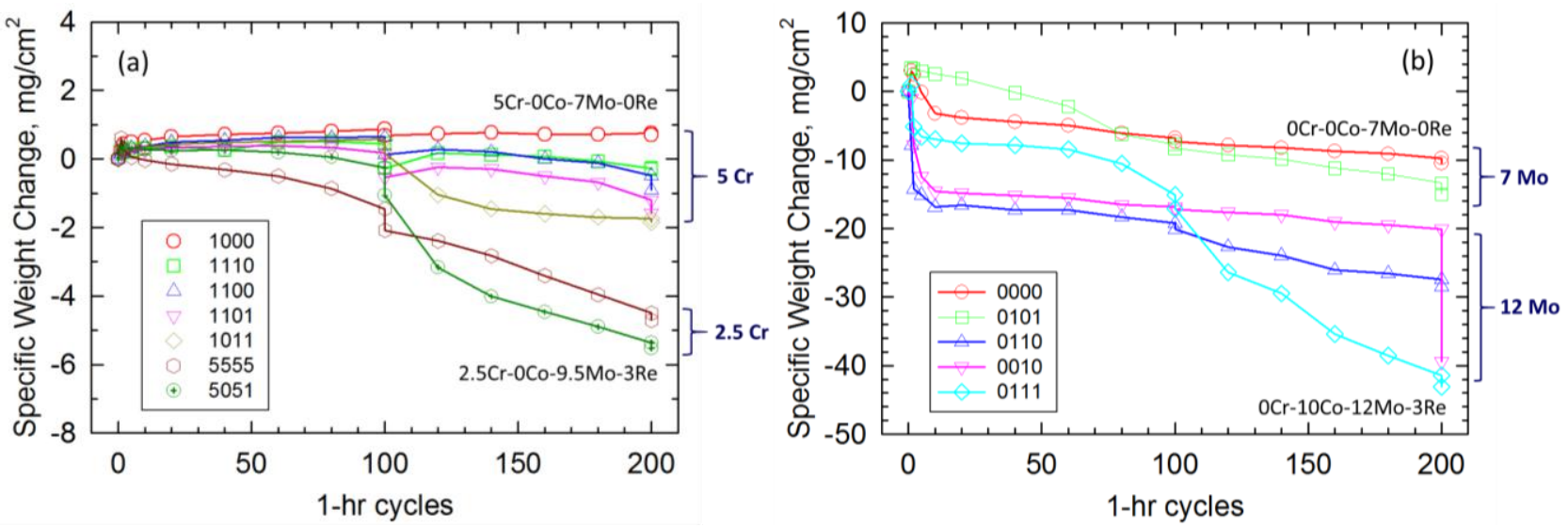

Figure 1. $1100{ }^{\circ} \mathrm{C}$ cyclic oxidation weight change for LDS VIM superalloys. (Cr, Co, Mo, Re) with 6.1 Al, 6.2 Ta, 50-100 ppm Y base composition. See Table 1 for (abcd) alloy code. (a) Cr-containing alloys exhibit moderate to good oxidation resistance, achieving small weight changes with minimal scale spallation; (b) Cr-Free alloys exhibit overall poor oxidation resistance, with weight losses $>10 \mathrm{mg} / \mathrm{cm}^{2}$ and severe scale spallation. 
Figure $1 \mathrm{~b}$ shows that the cyclic oxidation resistance of the alloys without $\mathrm{Cr}$ (0bcd) are severely degraded. The best alloy of this group, (0000), with $0 \% \mathrm{Cr}, 0 \% \mathrm{Co}, 7 \% \mathrm{Mo}$, and $0 \% \mathrm{Re}$, lost nearly $10 \mathrm{mg} / \mathrm{cm}^{2}$. However, the worst of the group lost $\sim 40 \mathrm{mg} / \mathrm{cm}^{2}$. This grouping exhibited some similar, but unusual, behavior characterized by a rapid initial mass loss followed by a less severe spalling rate. One alloy, (0010) with $12 \% \mathrm{Mo}$, lost an additional $20 \mathrm{mg} / \mathrm{cm}^{2}$ (vertical drop) due to ambient moisture effects after the test was completed at $200 \mathrm{~h}$.

A ranking of the alloys can be constructed based on final weight change as shown in Table 1 and Figure 1. Again, the major delimiter is the $\mathrm{Cr}$ content, with the performance of all the $5 \% \mathrm{Cr}$ alloys exceeding that of the $2.5 \% \mathrm{Cr}$ alloys, which in turn were better than all the $0 \% \mathrm{Cr}$ alloys. Note that the only alloy maintaining a positive weight change, about $+1 \mathrm{mg} / \mathrm{cm}^{2}$, was the higher $5 \% \mathrm{Cr}$ level with the lowest Mo (7\%) and no Co or Re, (1000). With the addition of Co, Mo, and Re, weight loss up to about $2 \mathrm{mg} / \mathrm{cm}^{2}$ is produced. Specifically, additions of Co, (1100) and (0110), all others being equal, tended to produce more severe weight loss at both the $5 \%$ and $0 \% \mathrm{Cr}$ level, respectively. At just $2.5 \% \mathrm{Cr}$, additional weight losses accrue $\left(-5 \mathrm{mg} / \mathrm{cm}^{2}\right)$, and with no $\mathrm{Cr}$, the weight loss can become severe ( -10 to $-40 \mathrm{mg} / \mathrm{cm}^{2}$ ). For each of the three alloy sets, grouped by $\mathrm{Cr}$ content as shown, the lowest rank was achieved by simultaneously high Mo and Re contents, (1011), (5051), (0111).

Since Co, Mo, and Re variations were generally made in combinations, it is difficult to assign a similar overarching trend for a given element. Rather, this compositional matrix was statistically designed to allow step-wise, multiple linear regression to extract significant parameters and describe the final $200 \mathrm{~h}$ weight change quantitatively. Here transformed compositional parameters $\left(P^{\prime}\right)$ were used: each composition parameter $(P)$ was adjusted by its midpoint $\left(P_{\text {mid }}\right)$, then normalized by half of its range of variation $(0.5 \Delta P): P^{\prime}=\left(P-P_{\mathrm{mid}}\right) /(0.5 \Delta P)$. Here actual measured compositions were used for preciseness rather than the nominal targets. Thus these parameters $P^{\prime}$ all vary from -1 to +1 , and the derived regression equation coefficients indicate the strength of effect relative to the elemental variation:

$$
\begin{gathered}
\Delta W / A\left(\mathrm{mg} / \mathrm{cm}^{2}\right) 1100^{\circ} \mathrm{C}, 200 \mathrm{~h}=-9.39+10.84 \times(\mathrm{Cr}-2.60) / 2.60-4.29 \times(\mathrm{Co}-5.11) / 5.11 \\
-5.267 \times(\mathrm{Mo}-9.66) / 2.60+3.91 \times((\mathrm{Cr}-2.60) / 2.60) \times((\mathrm{Mo}-9.66) / 2.60) \\
-3.74 \times((\mathrm{Mo}-9.66) / 2.60) \times((\mathrm{Re}-1.53) / 1.53)
\end{gathered}
$$

with a coefficient of determination $R^{2}=0.95$, adjusted for the number of estimated parameters $R_{\text {adj }}^{2}=0.90$, and root mean square residual error of $4.16 \mathrm{mg} / \mathrm{cm}^{2}$. The standard error of each coefficient amounted to $10 \%$ to $40 \%$ of the predicted weight change at the compositional limits. It is seen that there is a high positive coefficient $(+10.84)$ for $\mathrm{Cr}$ effects, a less positive $(+3.91) \mathrm{Cr} \times$ Mo product interaction coefficient, and negative Co, Mo, and Mo $\times$ Re coefficents. The positive $\mathrm{Cr} \times$ Mo interaction term indicates that higher Mo can be accommodated at higher $\mathrm{Cr}$ while maintaining oxidation resistance. However, the negative Mo $\times$ Re interaction term (-3.74) indicates that higher Mo could only be accommodated at lower Re while maintaining oxidation resistance. Other interaction terms were tested and found to be statistically insignificant. While not presented here, preliminary stepwise regression of weight change after $160 \mathrm{~h}$ had produced the same significant parameters, with estimates having the same signs and similar magnitudes to those at $200 \mathrm{~h}$. This helped confirm the robust applicability of the equation.

Due to the interaction terms, this equation implies complex and not a transparent mechanistic model of the oxidation behavior. However, it is useful for projecting performance for proposed alloying 
schemes within this compositional design space. The overall faithfulness of the regression fit can be visualized in Figure 2. Here the actual 200-h weight change is compared to that predicted by Equation (1). In general, a straight line with slope 1.03 and passing near the origin (0.12) is obtained with some deviations and $r^{2}=0.95$. Some specific alloys are labeled to help orient the trends. High $\mathrm{Cr}$ (1000) is at the top and the selected co-optimal alloy (1101) is nearby. The compositional midpoint (5555) is somewhat better than the prediction. The original high Mo, zero Cr, Co, Re (0010) alloy, is near the fitted line and well down the trend of poor oxidation resistance. The regression fit is seen to characterize the results over a large range of oxidation behavior. In order to represent the wide range exhibited by poor low $\mathrm{Cr}$ behavior, fine tuning the good behavior of the high $\mathrm{Cr}$ alloys may have been compromised.

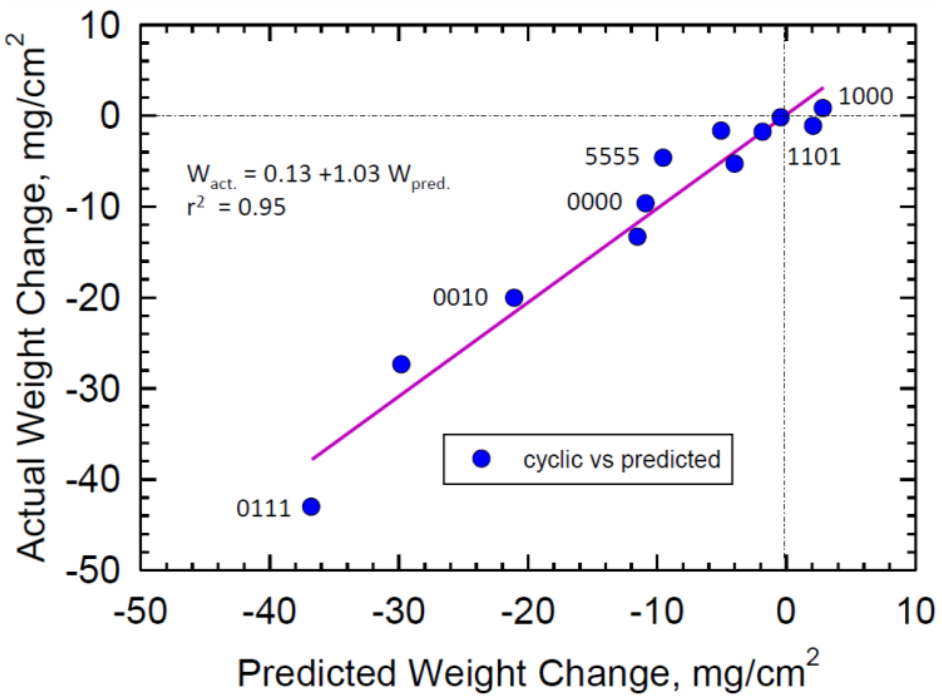

Figure 2. Distribution of actual $1100{ }^{\circ} \mathrm{C}, 200 \mathrm{~h}$ weight changes $v s$. those calculated from regression fitted Equation (1). Slope is $\sim 1.0$ and intercept $\sim 0.1 \mathrm{mg} / \mathrm{cm}^{2}$.

A general assessment of these alloys can be discerned by comparing these oxidation results to similar results obtained for common commercial alloys. Such a homogeneous data set is available from the Barrett cyclic oxidation database [24]. Accordingly, the $1100{ }^{\circ} \mathrm{C}, 200-\mathrm{h}$ cyclic oxidation weight change is tabulated with $\sim 30$ other alloys in order, Table 2. It is seen that the high Cr LDS alloys populate the upper level, in company with Rene' N5 \pm Y, Rene' N6, Rene' N4, and B1900. The 0\% Cr alloys populated a lower region bounded by Mar M $247(8 \% \mathrm{Cr}, 5.5 \% \mathrm{Al}, 10 \% \mathrm{~W})$ and $\mathrm{NX} 188(0 \% \mathrm{Cr}$, $8 \% \mathrm{Al}, 18 \% \mathrm{Mo})$.

As a further comparison to commercial alloys, long term $1100^{\circ} \mathrm{C}$ cyclic oxidation behavior of Rene' $\mathrm{N} 4$, Rene' N5 \pm Y, Rene' N6, and Rene' 80 were also obtained, Figure 3. It can be readily seen that the single crystal N5 and N6 alloys, having $4 \%-7 \% \mathrm{Cr}$ and $6 \% \mathrm{Al}$, performed very well. Rene' N4, with 9\% Cr, $3.7 \% \mathrm{Al}$ (and 4.2\% Ti), was inferior over this longer term. And Rene' 80, at just 3\% $\mathrm{Al}$ (and 14\% Cr), performed so poorly at this temperature that the test was terminated at $200 \mathrm{~h}$. This attests to the well-known synergy between $\mathrm{Cr}$ and $\mathrm{Al}$, requiring some $\mathrm{Cr}$ and a minimum $\mathrm{Al}$ content for protective $\mathrm{Al}_{2} \mathrm{O}_{3}$ scales, and complex (negative) effects caused by other alloying elements. 
Table 2. Comparative ranking of (a) LDS VIM alloys, (b) single crystals and (c) conventional commercial alloys for $1100{ }^{\circ} \mathrm{C}, 200 \mathrm{~h}$ cyclic oxidation mass change (From Barrett database).

\begin{tabular}{|c|c|c|c|c|}
\hline (a) LDS Code & $\begin{array}{c}\text { D.O.E. Composition } \\
(6.1 \mathrm{Al}, 6.2 \mathrm{Ta})\end{array}$ & $\Delta W / A, \mathrm{mg} / \mathrm{cm}^{2}$ & $\begin{array}{l}\text { (c) Commercial Alloy } \\
\text { Polycrystalline }\end{array}$ & $\Delta W / A, \mathrm{mg} / \mathrm{cm}^{2}$ \\
\hline $63-1000$ & $5 \mathrm{Cr}-7 \mathrm{Mo}$ & 0.75 & MarM 247 & -4.22 \\
\hline $58-1110$ & $5 \mathrm{Cr}-10 \mathrm{Co}-12 \mathrm{Mo}$ & -0.27 & IN 713 LC & -6.20 \\
\hline $57-1100$ & $5 \mathrm{Cr}-10 \mathrm{Co}-7 \mathrm{Mo}$ & -0.48 & Rene' $^{\prime} 125$ & -21.22 \\
\hline $68-1101$ & $5 \mathrm{Cr}-10 \mathrm{Co}-7 \mathrm{Mo}-3 \mathrm{Re}$ & -1.19 & MarM 246 & -24.44 \\
\hline $94-1011$ & $5 \mathrm{Cr}-12 \mathrm{Mo}-3 \mathrm{Re}$ & -1.73 & Astroloy & -30.25 \\
\hline $75-5555$ & $2.5 \mathrm{Cr}-5 \mathrm{Co}-9.5 \mathrm{Mo}-1.5 \mathrm{Re}$ & -4.50 & Rene' 120 & -38.57 \\
\hline $67-5051$ & $2.5 \mathrm{Cr}-9.5 \mathrm{Mo}-3 \mathrm{Re}$ & -5.36 & NX 188 & -48.76 \\
\hline $61-0000$ & $7 \mathrm{Mo}$ & -9.72 & MarM 200 & -53.59 \\
\hline $62-0101$ & $10 \mathrm{Co}-7 \mathrm{Mo}-3 \mathrm{Re}$ & -13.39 & U 700 & -55.21 \\
\hline $64-0010$ & $12 \mathrm{Mo}$ & -20.11 & MarM 421 & -74.11 \\
\hline $66-0110$ & $10 \mathrm{Co}-12 \mathrm{Mo}$ & -27.43 & Waspalloy & -79.29 \\
\hline 143 FHTSX & 14-Mo & -30.51 & MarM $200+$ Hf & -89.80 \\
\hline $95-0111$ & $10 \mathrm{Co}-12 \mathrm{Mo}-3 \mathrm{Re}$ & -41.44 & IN 792 & -166.26 \\
\hline 143 VIM & $14 \mathrm{Mo}$ & -95.57 & U 520 & -172.80 \\
\hline (b) Single Crystals & (5-6Al, 4-12Ta) & $\Delta W / A, \mathrm{mg} / \mathrm{cm}^{2}$ & IN 100 & -180.33 \\
\hline $\mathrm{H}_{2}$ PWA 1480 & $10 \mathrm{Cr}-4 \mathrm{~W}-1.5 \mathrm{Ti}(0.14 \mathrm{~S})$ & 0.61 & IN 939 & -227.60 \\
\hline Rene' N5- & $7 \mathrm{Cr}-5 \mathrm{~W}$ & 0.57 & IN 738 & -232.45 \\
\hline Rene' N6 & $4 \mathrm{Cr}-6 \mathrm{~W}$ & 0.56 & MarM 211 & -269.76 \\
\hline deS PWA 1484 & $5 \mathrm{Cr}-6 \mathrm{~W}(0.3 \mathrm{~S})$ & 0.49 & U 710 & -270.20 \\
\hline $\mathrm{H}_{2}$ PWA 1480 & $10 \mathrm{Cr}-4 \mathrm{~W}-1.5 \mathrm{Ti}(0.01 \mathrm{~S})$ & 0.45 & IN 718 & -284.60 \\
\hline Rene' N5+ & $7 \mathrm{Cr}-5 \mathrm{~W}+\mathrm{Y}$ & 0.41 & IN 625 & -293.20 \\
\hline PWA 1484 & $5 \mathrm{Cr}-6 \mathrm{~W}(1.2 \mathrm{~S})$ & 0.33 & U 720 & -313.50 \\
\hline Rene' N4 & $4 \mathrm{Al}-9 \mathrm{Cr}-6 \mathrm{~W}-4 \mathrm{Ti}$ & -1.07 & Rene' 80 & -330.35 \\
\hline PWA 1480 & $10 \mathrm{Cr}-4 \mathrm{~W}-1.5 \operatorname{Ti}(6.7 \mathrm{~S})$ & -7.44 & & \\
\hline
\end{tabular}

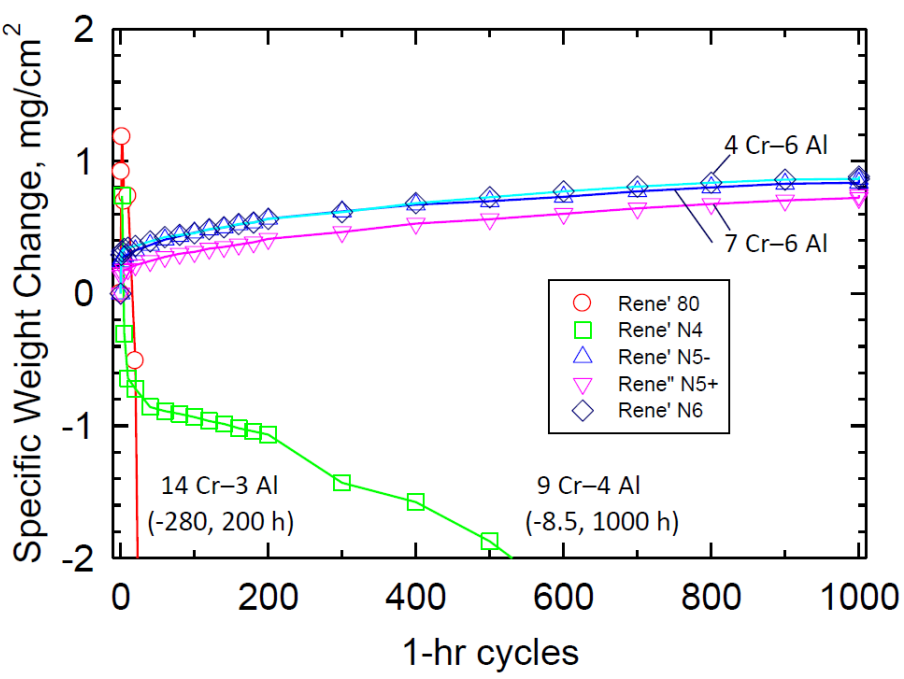

Figure 3. Long term $1100{ }^{\circ} \mathrm{C}$ cyclic oxidation weight change for commercial superalloys, showing superb behavior of high Al, zero Ti for Rene' N5, N6 single crystal superalloys as compared to low < 4Al, high > 4Ti for both Rene' N4 and 80. 


\subsection{X-ray Diffraction}

The phase content of the scales formed on this alloy set was determined by standard X-ray diffractometer scans. Sample surfaces and occasionally collected spall were analyzed. The phase analyses were remarkably similar, despite drastic differences in cyclic oxidation performance, as listed in Table 3 in decreasing order of oxidation resistance, from left to right. Typically, $\mathrm{NiO}, \mathrm{NiTa}_{2} \mathrm{O}_{6}, \mathrm{Ni}(\mathrm{Al}, \mathrm{Cr})_{2} \mathrm{O}_{4}$, and $\mathrm{Al}_{2} \mathrm{O}_{3}$ were the primary scale phases for nearly every alloy. It is expected that the order of intensity (top to bottom) was heavily affected by layering, with more transient Ni-rich phases lying in the outer region, with healing $\mathrm{Ni}(\mathrm{Al}, \mathrm{Cr})_{2} \mathrm{O}_{4}$ and inward growing $\alpha-\mathrm{Al}_{2} \mathrm{O}_{3}$ at the metal interface. The $\mathrm{Ni}(\mathrm{Al}, \mathrm{Cr})_{2} \mathrm{O}_{4}$ spinel are identified by lattice parameter, with Al-rich indicated by lower values and $\mathrm{Cr}$-rich for the higher values. No correlation of spinel lattice parameter with oxidation performance was obvious. $\mathrm{A} \mathrm{NiMoO}_{4}$ phase (with a better computer match to the published $\mathrm{CoMoO}_{4}$ pattern) was identified on the poorest performing alloy, (0111), having a high Mo content. This Mo-rich scale phase was only identified on this sample, while all samples contained at least 7\%-12\% Mo. By comparison, the commercial alloys (Table 4) show some of these scale phases, additionally with $\mathrm{TiO}_{2}$ for Rene' 80 and Rene' N4. Finally, the preliminary alloy set that corresponds to the same samples examined by SEM are presented in Table 5. $\mathrm{NiO}, \mathrm{NiAl}_{2} \mathrm{O}_{4}$ spinel, and $\mathrm{NiTa}_{2} \mathrm{O}_{6}$ tri-rutile are again the primary phases identified. Fairly similar results are shown by alloy type and between retained and spalled scales.

Table 3. XRD analysis of scale phases formed on $12 \mathrm{LDS}$ alloys after $200 \mathrm{~h}$ cyclic oxidation at $1100{ }^{\circ} \mathrm{C}$ corresponding to data in Figure 1. Listed in order of pattern strength, strongest to weakest. Spinel lattice parameters generally indicate $\mathrm{Al}$ predominance over $\mathrm{Cr}$.

\begin{tabular}{|c|c|c|c|c|c|}
\hline Alloy & Scale Phases & Alloy & Scale Phases & Alloy & Scale Phases \\
\hline \multirow{4}{*}{$63-1000$} & $\mathrm{NiO}$ & \multirow{4}{*}{ 94-1011 } & $\mathrm{NiO}$ & \multirow{4}{*}{$62-0101$} & $\mathrm{NiO}$ \\
\hline & $\mathrm{Al}_{2} \mathrm{O}_{3}$ & & $\mathrm{NiTa}_{2} \mathrm{O}_{6}$ & & $\mathrm{NiTa}_{2} \mathrm{O}_{6}$ \\
\hline & $\mathrm{NiTa}_{2} \mathrm{O}_{6}$ & & spinel, $8.15 \AA$ & & spinel, $8.10 \AA$ \\
\hline & spinel, $8.10 \AA$ & & $\mathrm{Al}_{2} \mathrm{O}_{3(\mathrm{~m})}$ & & $\mathrm{Al}_{2} \mathrm{O}_{3(\mathrm{vm})}$ \\
\hline \multirow{4}{*}{$58-1110$} & $\mathrm{NiO}$ & \multirow{4}{*}{$75-5555$} & $\mathrm{NiO}$ & \multirow{4}{*}{$66-0110$} & $\mathrm{NiO}$ \\
\hline & spinel, $8.30 \AA$ & & $\mathrm{NiTa}_{2} \mathrm{O}_{6}$ & & $\mathrm{NiTa}_{2} \mathrm{O}_{6}$ \\
\hline & $\mathrm{NiTa}_{2} \mathrm{O}_{6}$ & & spinel, $8.10 \AA$ & & spinel, $8.10 \AA$ \\
\hline & $\mathrm{Al}_{2} \mathrm{O}_{3(\mathrm{~m})}$ & & $\mathrm{Al}_{2} \mathrm{O}_{3(\mathrm{vm})}$ & & $\mathrm{Al}_{2} \mathrm{O}_{3(\mathrm{vm})}$ \\
\hline \multirow{4}{*}{$57-1100$} & $\mathrm{NiO}$ & \multirow{4}{*}{$67-5051$} & $\mathrm{NiTa}_{2} \mathrm{O}_{6}$ & \multirow{4}{*}{$64-0010$} & $\mathrm{NiO}$ \\
\hline & $\mathrm{Al}_{2} \mathrm{O}_{3}$ & & $\mathrm{NiO}$ & & $\mathrm{NiTa}_{2} \mathrm{O}_{6}$ \\
\hline & spinel, $8.10 \AA$ & & spinel, $8.10 \AA$ & & spinel, $8.10 \AA$ \\
\hline & $\mathrm{NiTa}_{2} \mathrm{O}_{6}$ & & $\mathrm{Al}_{2} \mathrm{O}_{3(\mathrm{~m})}$ & & $\mathrm{Al}_{2} \mathrm{O}_{3(\mathrm{vm})}$ \\
\hline \multirow{4}{*}{$68-1101$} & $\mathrm{NiO}$ & \multirow{4}{*}{ 61-0000 } & $\mathrm{NiO}$ & \multirow{4}{*}{$95-0111$} & $\mathrm{NiO}$ \\
\hline & $\mathrm{NiTa}_{2} \mathrm{O}_{6}$ & & $\mathrm{NiTa}_{2} \mathrm{O}_{6}$ & & $\mathrm{NiTa}_{2} \mathrm{O}_{6}$ \\
\hline & spinel, $8.15 \AA$ & & spinel, $8.05 \AA$ & & spinel, $8.10 \AA$ \\
\hline & - & & $\mathrm{Al}_{2} \mathrm{O}_{3(\mathrm{~m})}$ & & $\mathrm{CoMoO}_{4}$ \\
\hline
\end{tabular}

Note: $\mathrm{m}=$ minor, vm = very minor. Spinels: $\mathrm{NiAl}_{2} \mathrm{O}_{4}, \mathrm{a}_{0}=8.05 \AA$ 知 $\mathrm{Nr}_{2} \mathrm{O}_{4}, \mathrm{a}_{0}=8.32 \AA$. 
Table 4. XRD analysis of scale phases formed on commercial superalloys after $1000 \mathrm{~h}$ cyclic oxidation at $1100{ }^{\circ} \mathrm{C}$ corresponding to mass change data in Figure 2. (Listed in order of pattern strength, strongest to weakest).

\begin{tabular}{|c|c|}
\hline Alloy & Scale Phases $\left(1100{ }^{\circ} \mathrm{C}, 1000 \mathrm{~h}\right)$ \\
\hline \multirow{5}{*}{ Rene' 80 (200 h) } & $\mathrm{NiO}$ \\
\hline & spinel, $8.35 \AA$ \\
\hline & $\mathrm{TiO}_{2}$ \\
\hline & $\mathrm{Cr}_{2} \mathrm{O}_{3}$ \\
\hline & $\mathrm{Ni}(\mathrm{Mo}, \mathrm{W}) \mathrm{O}_{4}$ \\
\hline \multirow{3}{*}{ Rene' N4 (1000 h) } & spinel, $8.10 \AA$ \\
\hline & $\mathrm{TiO}_{2}$ \\
\hline & $\mathrm{Al}_{2} \mathrm{O}_{3}$ \\
\hline \multirow{3}{*}{ Rene' N5 (1000 h) } & $\mathrm{NiTa}_{2} \mathrm{O}_{6}$ \\
\hline & spinel, $8.10 \AA$ \\
\hline & $\mathrm{Al}_{2} \mathrm{O}_{3}$ \\
\hline \multirow{3}{*}{ Rene' $^{\prime}$ N5 + Y (1000 h) } & $\mathrm{NiTa}_{2} \mathrm{O}_{6}$ \\
\hline & spinel, $8.10 \AA$ \\
\hline & $\mathrm{Al}_{2} \mathrm{O}_{3}$ \\
\hline \multirow{4}{*}{ Rene' N6 (1000 h) } & spinel, $8.10 \AA$ \\
\hline & $\mathrm{NiO}$ \\
\hline & $\mathrm{NiTa}_{2} \mathrm{O}_{6}$ \\
\hline & $\mathrm{Al}_{2} \mathrm{O}_{3}$ \\
\hline
\end{tabular}

Table 5. XRD summary of scale phases formed on preliminary LDS castings corresponding to SEM characterizations in Figures $4-11$. (200 h cyclic oxidation at $\left.1100{ }^{\circ} \mathrm{C}\right)$.

\begin{tabular}{|c|c|c|c|c|c|c|c|c|c|}
\hline Sample & LDS & $\% \mathrm{Cr}$ & $\begin{array}{l}\text { Weight, } \\
\text { mg/cm² }\end{array}$ & $\alpha-\mathrm{Al}_{2} \mathrm{O}_{3}$ & $\begin{array}{c}\text { Spinel } \\
\mathrm{Ni}(\mathrm{Al}, \mathrm{Cr})_{2} \mathrm{O}_{4}\end{array}$ & $\mathbf{a}_{0}, \AA$ & $\begin{array}{c}\text { Rutile } \\
(\mathrm{Ni}, \mathrm{Cr}) \mathrm{Ta}_{2} \mathrm{O}_{6}\end{array}$ & $\mathrm{NiO}$ & $\mathbf{N i}$ \\
\hline 2-49 surface & 1011 & $5 \mathrm{Cr}$ & -4.70 & & $\mathrm{~W}$ & 8.15 & $\mathrm{~W}$ & $S$ & VS \\
\hline 2-49 spall & 1011 & $5 \mathrm{Cr}$ & & & W & 8.10 & $\mathrm{~W}$ & $S$ & - \\
\hline 2-51 surface & 1011 & $5 \mathrm{Cr}$ & -7.88 & & M & 8.15 & M & S & VS \\
\hline 2-51 spall & 1011 & $5 \mathrm{Cr}$ & & & M & 8.07 & M & $S$ & - \\
\hline 2-50 surface & 5555 & $2.5 \mathrm{Cr}$ & -52.98 & & $\mathrm{~W}$ & 8.10 & M & $S$ & VS \\
\hline 2-50 spall & 5555 & $2.5 \mathrm{Cr}$ & & & $\mathrm{W}$ & 8.10 & $\mathrm{~W}$ & VS & - \\
\hline 2-48 surface & 0010 & $0 \mathrm{Cr}$ & -109.23 & & M & 8.05 & M & $S$ & - \\
\hline 2-48 spall & 0010 & $0 \mathrm{Cr}$ & & & W & 8.03 & $\mathrm{~W}$ & $S$ & - \\
\hline 143 VIM surface & 0010 & $0 \mathrm{Cr}$ & -95.57 & & $\mathrm{~W}$ & 8.05 & M & VS & $\mathrm{S}$ \\
\hline 143 VIM spall & 0010 & $0 \mathrm{Cr}$ & & VVW & $\mathrm{W}$ & 8.05 & M & VS & - \\
\hline $143 \mathrm{SX}$ surface & 0010 & $0 \mathrm{Cr}$ & -30.51 & & $\mathrm{~W}$ & 8.05 & $\mathrm{~W}$ & VS & - \\
\hline 143 SX spall & 0010 & $0 \mathrm{Cr}$ & & VVW & $\mathrm{M}$ & 8.05 & M & VS & - \\
\hline
\end{tabular}




\subsection{Scanning Electron Microscopy}

Generally this class of alloys forms a layered scale, with transient Ni-rich scales $\left(\mathrm{NiO}, \mathrm{NiAl}_{2} \mathrm{O}_{4}\right.$ and $\mathrm{NiTa}_{2} \mathrm{O}_{6}$ ) at the outer surface and a slow growing protective $\mathrm{Al}_{2} \mathrm{O}_{3}$ layer closest to the substrate. The $\mathrm{NiTa}_{2} \mathrm{O}_{6}$ normally takes the form of fine spherical particles on the surface and appear very bright in backscatter electron imaging. Since the distinguishing factor of this low density set of alloys is the high Mo content, an effort was made to look for distinctive Mo containing features in the scale, most likely present as $\mathrm{NiMoO}_{4}$. Consequently, SEM (BSE) characterizations were performed for a preliminary (0010) alloy, 2-48, having high Mo and no $\mathrm{Cr}$ and therefore a greater propensity for Mo-induced accelerated oxidation.

Multiple scale thicknesses on the sample surface resulted from repeated spalling and regrowth that was non-uniform on this fine scale. Other regions of spalling to bare metal were apparent. The general structure of one region can be seen in Figure 4, with relatively flat scale on the right, large faceted grains in the center, and fine grains with surface precipitates on top of these. The distinctive large faceted $\mathrm{NiO}$ surface grain structure can be seen in Figure 5. In some areas, they are intermingled with fine grains on their surface (Figure 5a), others are relatively uniform, clean, faceted crystals (Figure 5b). Mo-rich features were not observed. To that point, a large scale spall fragment was collected and examined, Figure 6. It was found that the underlying, rather fragmented, granular features were extremely Mo-rich (points 2,3). The fine Ta-rich nodules, identified by EDS, (point 4), again lay on top of these. It is therefore expected that this represents an outer surface of a thick, perhaps original, scale segment. Another spalled segment from an $1100^{\circ} \mathrm{C}, 100$-h TGA test of a $0 \% \mathrm{Cr}-14 \%$ Mo alloy (\# 143) also exhibited isolated Mo-rich features, but less frequent and partially decomposed.

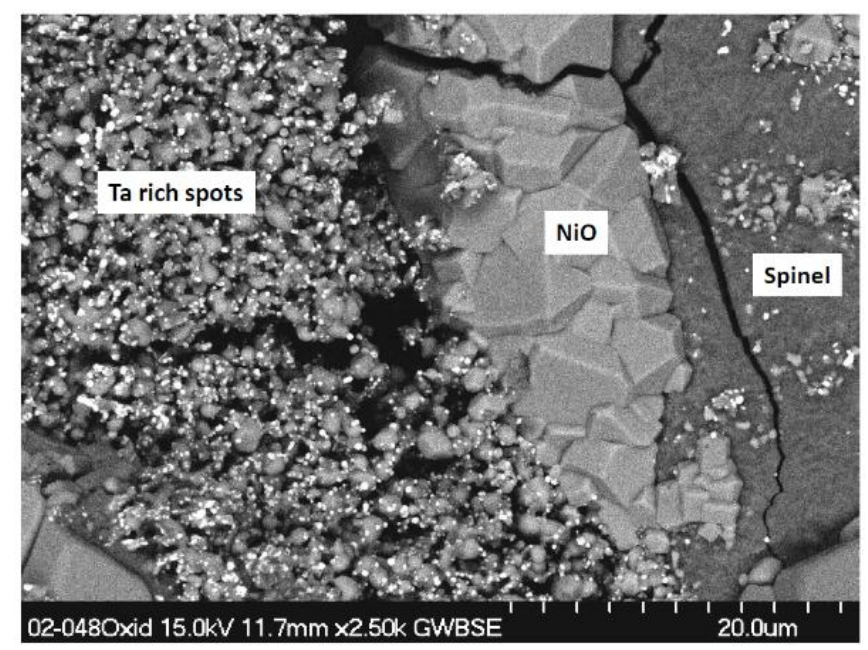

Figure 4. Representative alloy surface scale microstructures remaining on a high Mo alloy 2-48: (0010) after $200 \mathrm{~h}$ cyclic oxidation at $1100{ }^{\circ} \mathrm{C}$. Features for $\mathrm{NiO}, \mathrm{NiAl}_{2} \mathrm{O}_{4}$, and $\mathrm{NiTa}_{2} \mathrm{O}_{6}$ are represented. 


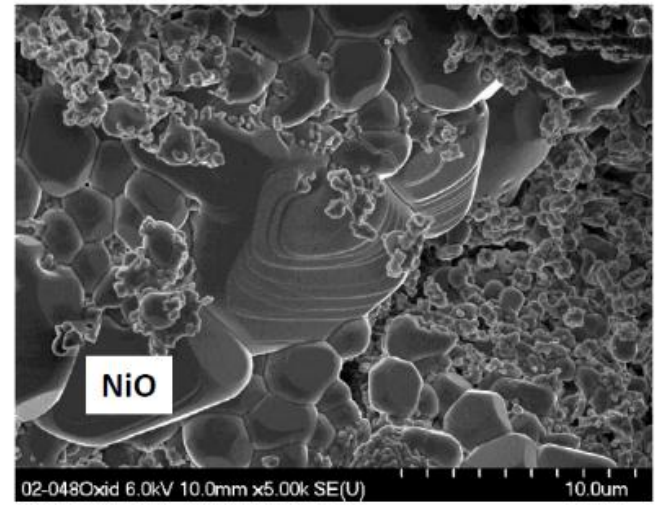

(a)

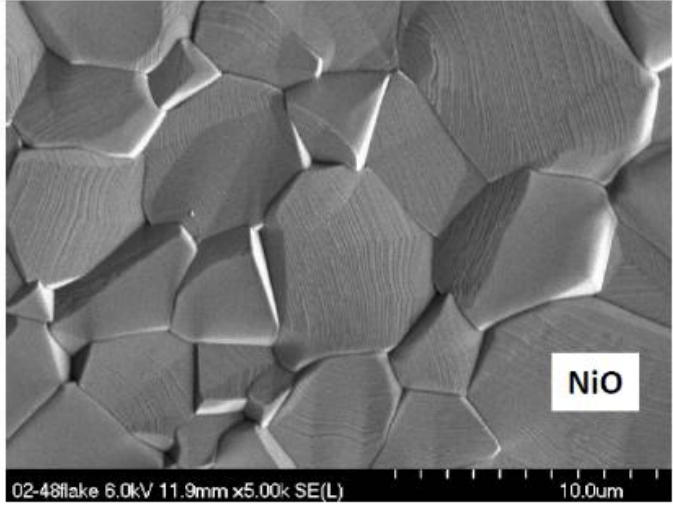

(b)

Figure 5. Characteristic large $\mathrm{NiO}$ grains in scales formed on high 12\% Mo alloy 2-48 (0010). (a) SEM/SE image of sample surface; (b) SEM/BSE image of large spalled flake. $200 \mathrm{~h}$ cyclic oxidation at $1100{ }^{\circ} \mathrm{C}$.

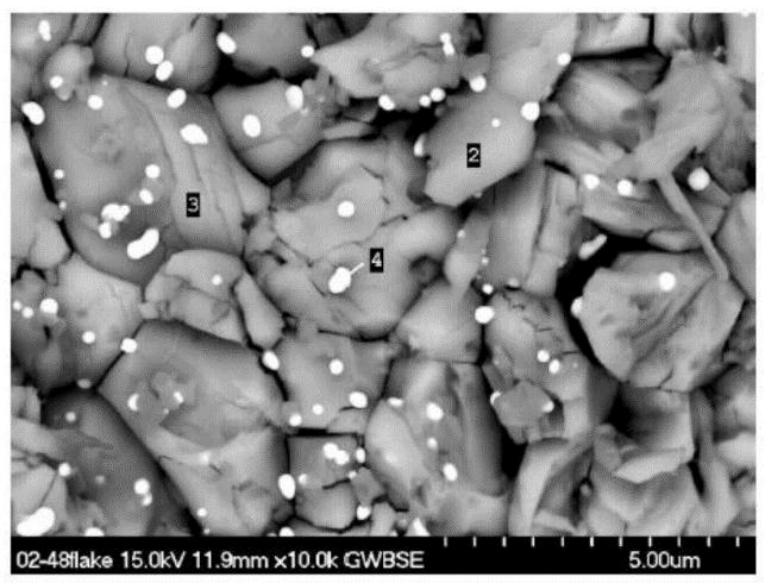

Figure 6. Micro-laminated high Mo oxide grains underlying Ta-rich spheroids. Spalled flake from high $12 \%$ Mo (0010) alloy 2-48 after $200 \mathrm{~h}$ cyclic oxidation at $1100{ }^{\circ} \mathrm{C}$.

Correspondingly, one can see the appropriate EDS spectra in Figure 7a-d showing: (a) high Ni for the large $\mathrm{NiO}$ crystals; (b) high $\mathrm{Al}$ for the flat $\mathrm{NiAl}_{2} \mathrm{O}_{4}$ plateau region in Figure 4; (c) a mixture of fine grain $\mathrm{Al}_{2} \mathrm{O}_{3}$ with $\mathrm{NiTa}_{2} \mathrm{O}_{6}$ particles; and (d) Mo-rich $\mathrm{NiMoO}_{4}$ grains (Figure 6).

At $2.5 \% \mathrm{Cr}$, alloy 2-50 (5555) similar features can be recognized in the detailed microstructure of Figure 8. Finally, at 5\% Cr, alloy 2-49 (1011) some new features are presented, Figure 9. Large (bright) areas of spalling to bare metal are now observed, as verified by the oxide grain imprint morphology at higher magnification and EDS spectra with high Ni, Mo, Ta peaks. This is consistent with alumina-formers where interfacial spallation occurs. Other features in Figure $9 \mathrm{~b}$ appear more typical of those described for $0 \%$ and $2.5 \%$ Cr previously, as are the Ta-rich spheroids in Figures 10 and 11 shows dark regions of fractured $\mathrm{Al}_{2} \mathrm{O}_{3}$, identified by XRD primarily for the $5 \% \mathrm{Cr}$ alloys. However these regions were quite complex and suggest multiple random spalling/regrowth features. No new Mo-rich regions were found except for the spalled flakes previously discussed. Some large grain $\mathrm{NiO}$ grain clusters were observed, but much of the area was covered with $\mathrm{Ni}(\mathrm{Al}, \mathrm{Cr})_{2} \mathrm{O}_{4}$. 

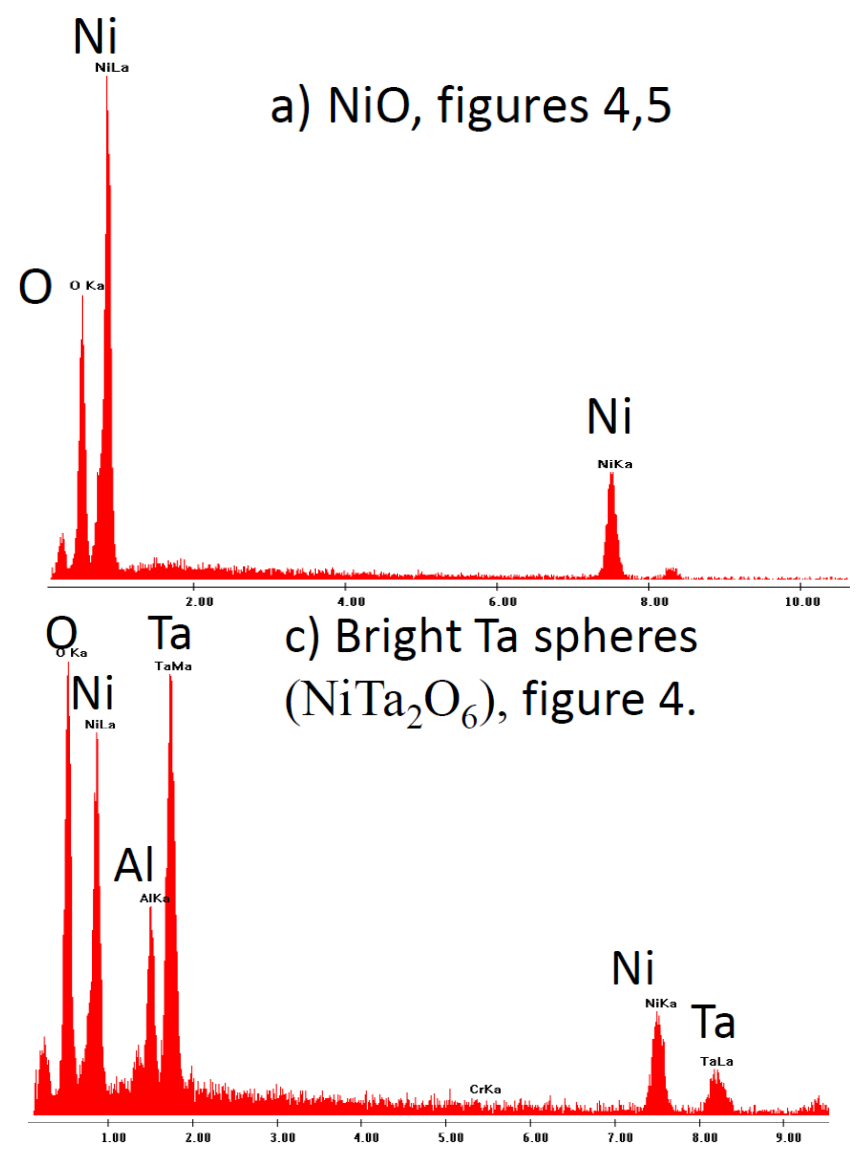
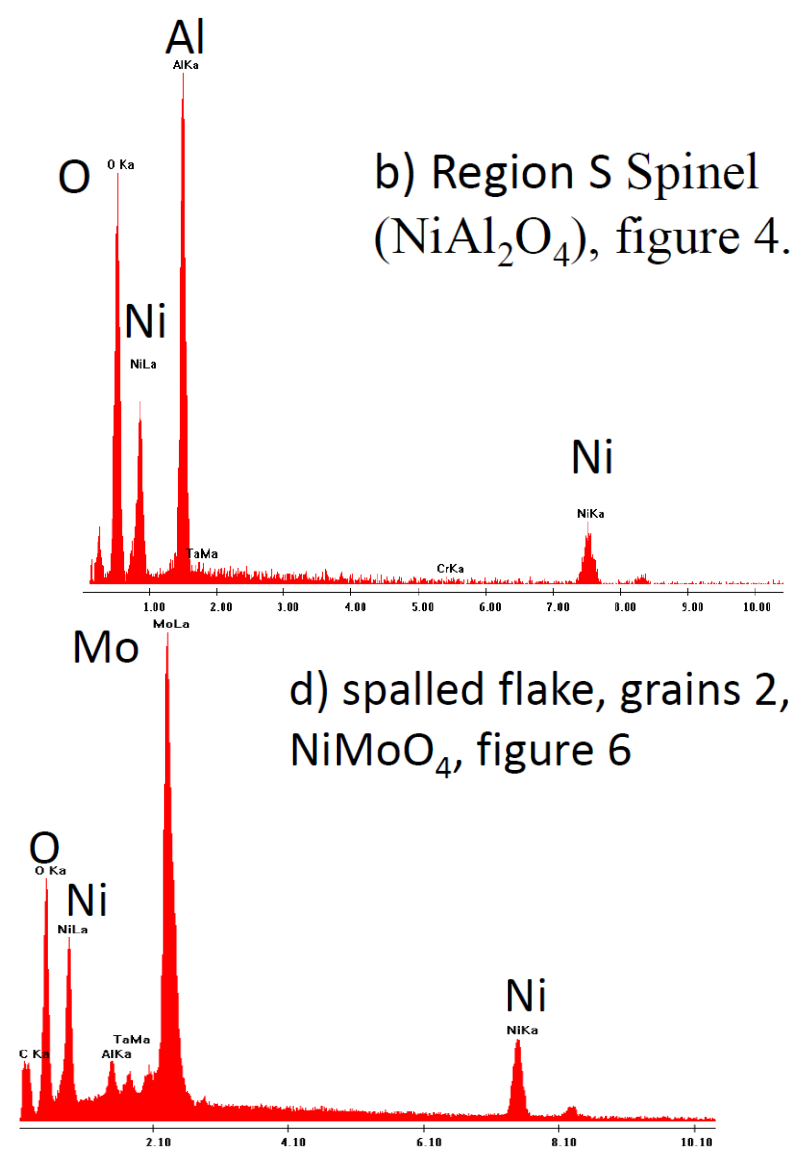

Figure 7. Typical EDS profiles corresponding to representative Ni-, Al-, Ta-, and Mo-rich features for high $12 \%$ Mo (0010) alloy 2-48, $200 \mathrm{~h}$ cyclic oxidation at $1100{ }^{\circ} \mathrm{C}$. (a) large, striated $\mathrm{NiO}$ grains (Figure 5a); (b) flat $\mathrm{NiAl}_{2} \mathrm{O}_{4}$ plateau (Figure 4); (c) bright $\mathrm{NiTa}_{2} \mathrm{O}_{6}$ topmost spheroids (Figure 4); and (d) underlying $\mathrm{NiMoO}_{4}$ grains from spalled flake (Figure 6), respectively.

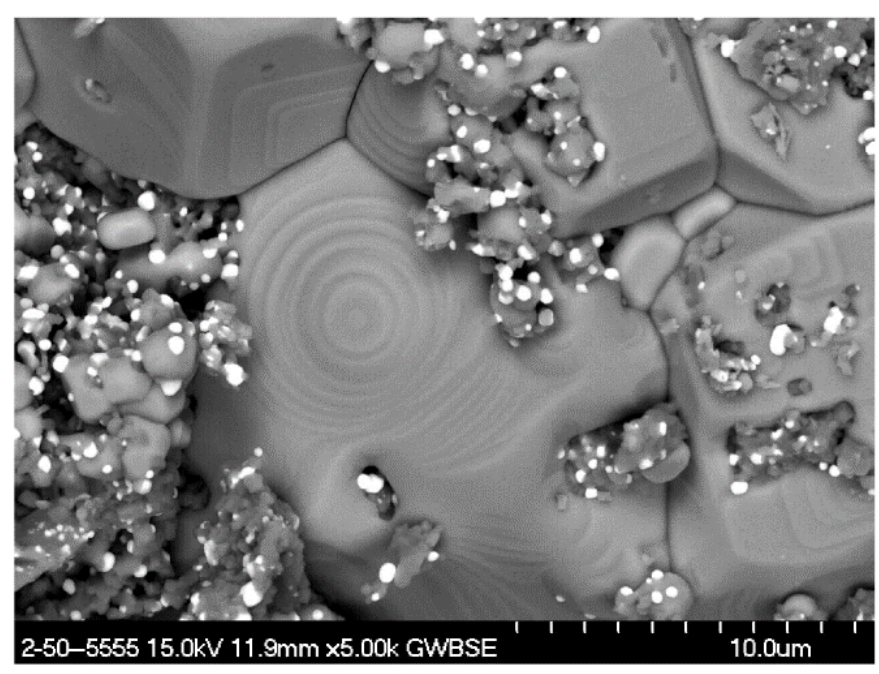

Figure 8. Scale features on midpoint alloy 2-50, (5555). Large $\mathrm{NiO}$ grains with growth facets, small $\mathrm{NiTa}_{2} \mathrm{O}_{6}$ spheroids atop $\mathrm{NiAl}_{2} \mathrm{O}_{4}$ fine grains. $200 \mathrm{~h}$ cyclic oxidation at $1100{ }^{\circ} \mathrm{C}$. 


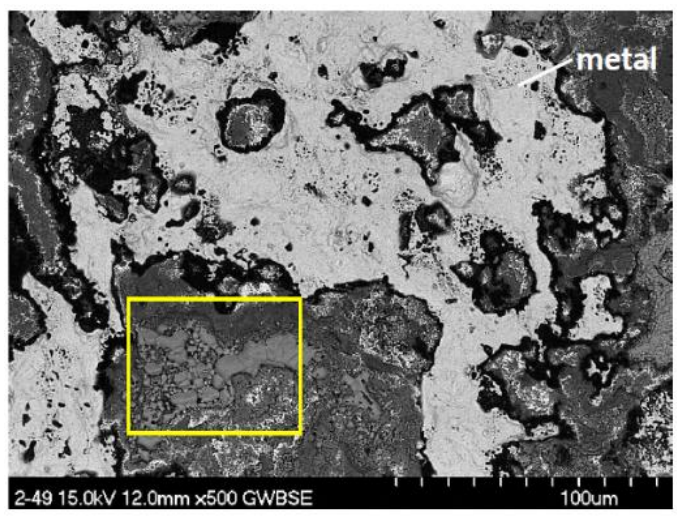

(a)

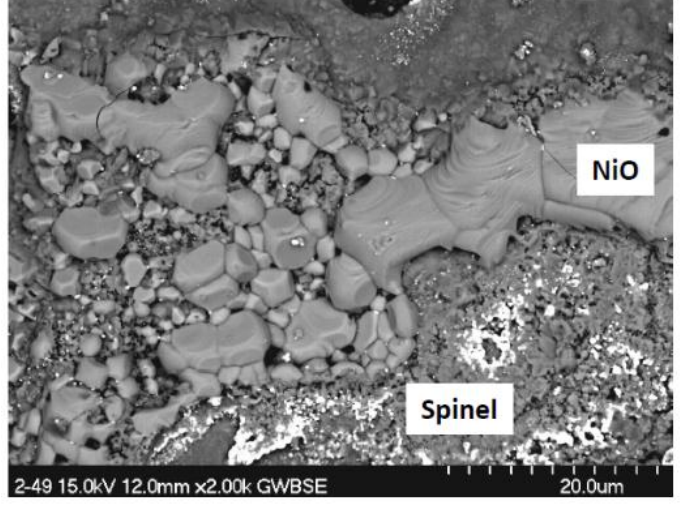

(b)

Figure 9. Oxidized surface of high Cr, Mo, Re alloy 2-49, (1011). (a) Bright areas of spalling to bare metal; (b) detail of (a) showing isolated colony of large $\mathrm{NiO}$ grains with growth facets. $200 \mathrm{~h}$ cyclic oxidation at $1100{ }^{\circ} \mathrm{C}$.

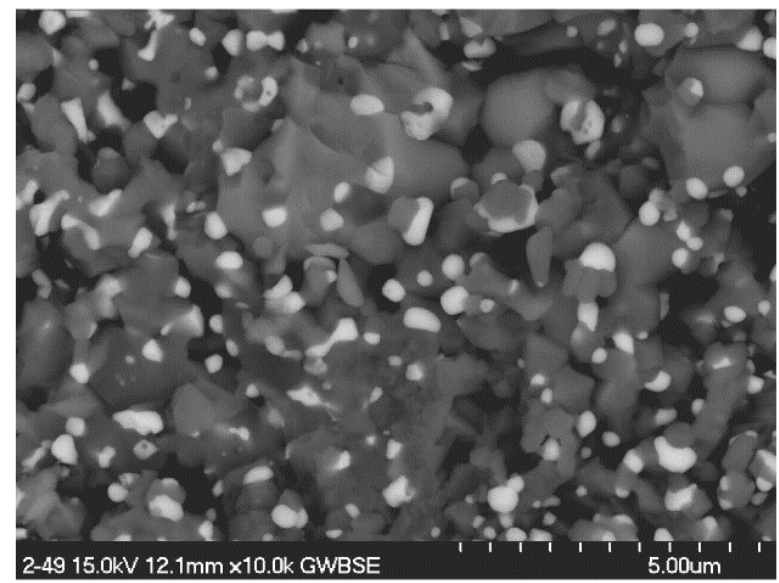

Figure 10. Small $\mathrm{NiTa}_{2} \mathrm{O}_{6}$ spheroids atop $\mathrm{NiAl}_{2} \mathrm{O}_{4}$ fine grains on 2-49 alloy (1011). $200 \mathrm{~h}$ cyclic oxidation at $1100^{\circ} \mathrm{C}$.
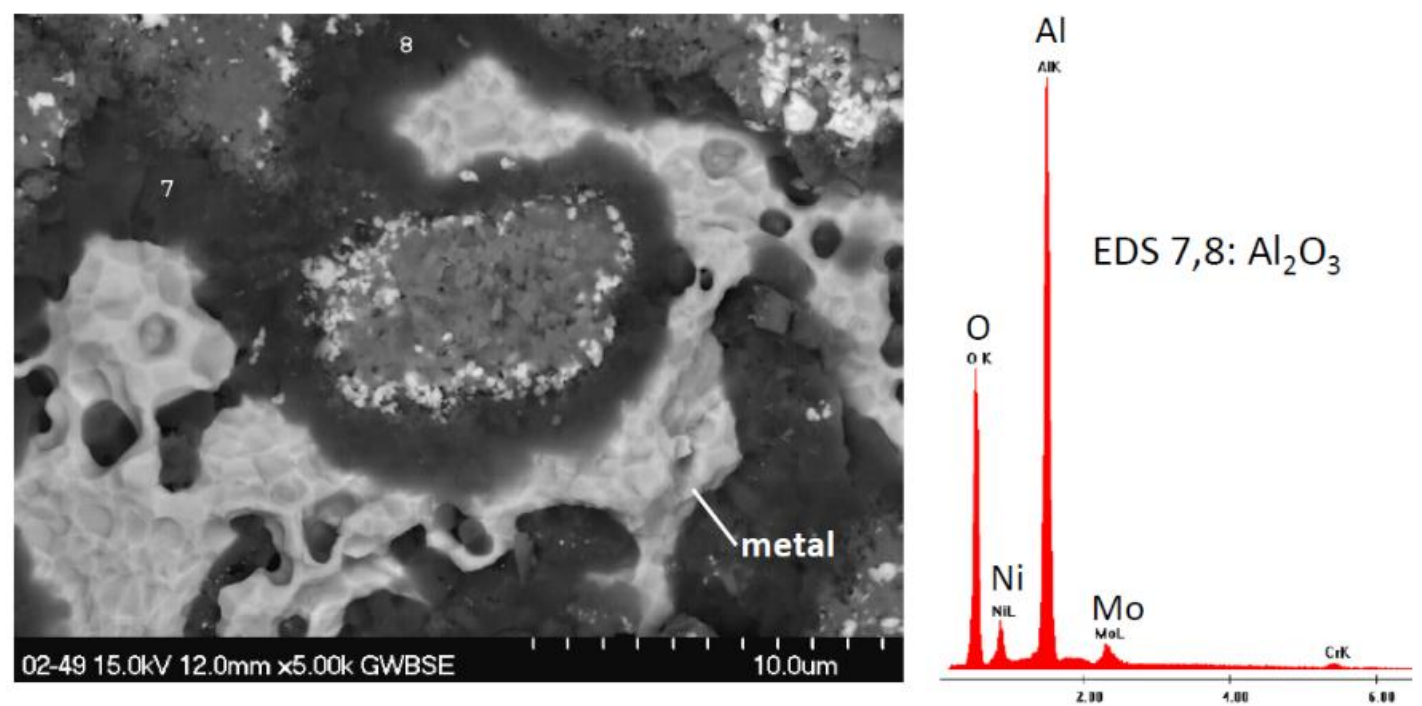

Figure 11. Dark $\mathrm{Al}_{2} \mathrm{O}_{3}$ bands and bright exposed metal features on 2-49 alloy (1011). $200 \mathrm{~h}$ cyclic oxidation at $1100{ }^{\circ} \mathrm{C}$. 


\subsection{TGA Results}

Continuous thermogravimetric analysis was only performed on selected samples with high Mo content for the purpose of $\mathrm{NiMoO}_{4}$ elucidation. The unusual results for a heat treated early single crystal alloy (\# 143 at 14\% Mo) are shown in Figure 12 and are believed to represent behavior of other high 12\% Mo alloys. Here a large initial mass gain of $4.6 \mathrm{mg} / \mathrm{cm}^{2}$ is observed in the first $10 \mathrm{~h}$, followed by a gradual weight loss of $50 \%$ of this maximum to $2.3 \mathrm{mg} / \mathrm{cm}^{2}$ after $100 \mathrm{~h}$. Optical and SEM microscopy identified large $\mathrm{NiO}$ grains in a thick outer scale. The underside of the spalled scale was also primarily large grained $\mathrm{NiO}$, with clusters of smaller $\mathrm{Ni}(\mathrm{Al}, \mathrm{Cr})_{2} \mathrm{O}_{4}$ spinel grains, dotted with Ta-rich particles, Figure 13 . Only limited areas exhibited Mo-rich features, such as the feathery mound in the center of this image (circled).

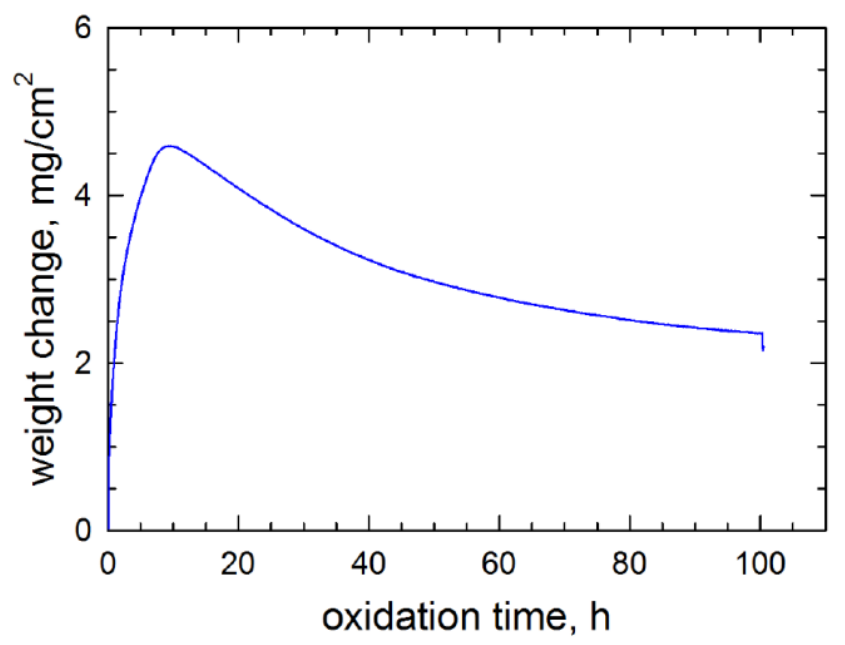

Figure 12. $1100{ }^{\circ} \mathrm{C}, 100 \mathrm{~h}$ TGA response for a Ni-6Al-6Ta-14Mo alloy (\# 143) in air. A rapid increase of $5 \mathrm{mg} / \mathrm{cm}^{2}$ is followed by a gradual loss of $2 \mathrm{mg} / \mathrm{cm}^{2}$.
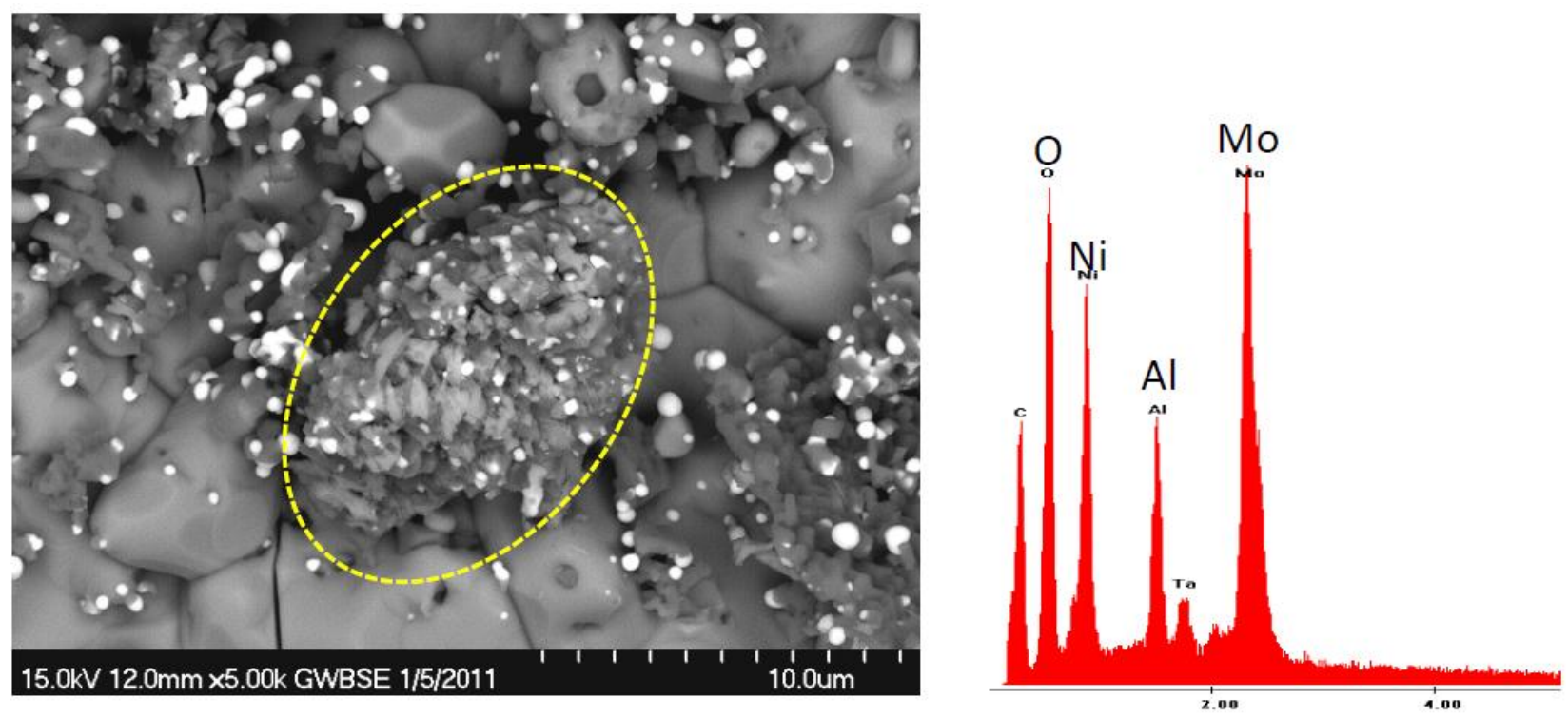

Figure 13. BSE/SEM and EDS spectra of a high Mo, flakey nodule (circled) on a NiO base scale. From detached flake of the TGA sample (\# 143) in Figure 12. 


\section{Discussion}

\subsection{Compositional Effects on Oxidative Mass Changes}

The cyclic oxidation results above show an extensive range of behaviors produced by the D.O.E. matrix of compositional variations for $\mathrm{Cr}, \mathrm{Co}, \mathrm{Mo}$, and Re. Final weight changes after 2001 -h cycles at $1100{ }^{\circ} \mathrm{C}$ varied from widely about $-40 \mathrm{mg} / \mathrm{cm}^{2}$ to $+1 \mathrm{mg} / \mathrm{cm}^{2}$. From an engineering standpoint, behavior similar to that of highly oxidation resistant 2 nd generation single crystal superalloys was approached in this preliminary screening test. This was accomplished in large part by retaining some key elements at the same levels (6\% Al, 6.2\% Ta, and no Ti). Of the four experimental design parameters, $\mathrm{Cr}$ is extremely necessary, as expected, and substitution of $\mathrm{W}$ by higher levels of Mo could be tolerated. $\mathrm{Cr}$ promoted thinner scales and less spallation.

Stepwise multiple linear regression produced a statistically significant equation that reproduced the major experimental trends within the compositional matrix, allowing further interpolation within that defined compositional space. The coefficients reflect the strong positive effect of $\mathrm{Cr}$ and lesser negative effects of Mo, including a positive $\mathrm{Cr} \times \mathrm{Mo}$ and a negative $\mathrm{Mo} \times \mathrm{Re}$ interaction term. The negative effect of $\mathrm{Co}$, a common low level substitute for $\mathrm{Ni}$ in most single crystal superalloys, is surprising and unexplained at present. The effect of $\mathrm{Cr}$ follows established principles for dilute $\mathrm{Ni}-\mathrm{Al}$ alloys in which transient $\mathrm{Cr}_{2} \mathrm{O}_{3}$ (and $\mathrm{Ni}(\mathrm{Al}, \mathrm{Cr})_{2} \mathrm{O}_{4}$ ) scales assist in preventing rapid growing, non-protective $\mathrm{NiO}$ scale formation on isothermal and cyclic oxide maps [2,25,26], but with a greatly expanded transition region for cyclic behavior [2]. This allows time for a protective $\mathrm{Al}_{2} \mathrm{O}_{3}$ healing layer to form and establish slower oxidative rate control. The Y-dopant levels in the preliminary alloys studied by SEM, 2-48 (0010), 2-49 and 2-51 (1011), were notably below target levels, being only on the order of 5-10 ppm. This may not have been sufficient to maximize $\mathrm{Al}_{2} \mathrm{O}_{3}$ scale adhesion, as predicated by a critical $\mathrm{Y} / \mathrm{S}$ ratio $\approx 3$ (1:1 atomic) [7]. The notable spalling to bare metal (Figures 9 and 11) suggests that the Y present was not completely effective or that additional factors were operative other than sulfur segregation mechanisms. The corresponding weight losses in Table 5 were considerably more severe than the 12 alloy VIM D.O.E. series having 50-100 ppm Y, Table 1.

Other mass change features distinguish this set of 12 alloys. There appears to be a rapid uptake of $\sim 3 \mathrm{mg} / \mathrm{cm}^{2}$ for the first hour for some $\mathrm{Cr}$-free alloys that would be abnormal for most commercial single crystal alloys. This is believed to be due to rapid $\mathrm{NiO}$ layer growth and complete spallation, as portrayed in macrographs of loose scale formed on single crystals after $1 \mathrm{~h}$. [21] It is then moderated to lower growth and spallation of a different scale chemistry. Some similarities can be seen for the Rene' N4 weight data to some degree. External $\mathrm{NiO}$ growth is predicted for isothermal oxidation of alloys with low $\mathrm{Cr}$ and $\mathrm{Al}$ levels that fall below the boundary required for external $\mathrm{Al}_{2} \mathrm{O}_{3}$ scales. But the transition zone to protective behavior is widened to higher $\mathrm{Cr}$, $\mathrm{Al}$ contents under cyclic conditions, as indicated on cyclic oxidation maps [2,26].

\subsection{Effects of High Mo Content on Oxidation}

The effect of high Mo contents is more elusive. From the X-ray diffraction results in Table 2, a distinct Mo-rich scale phase $\left(\mathrm{NiMoO}_{4}\right)$ only appeared on one poor performing alloy (0111), despite similar Mo contents in alloys (0010) and (0110). However in limited SEM surveys of scale features, distinct high 
Mo grains were found for the high Mo (0010) alloys. It is expected that these scales may be transient in light of Mo losses by $\mathrm{MoO}_{3}$ vaporization. The gradual but extensive weight loss in the TGA test of the high Mo single crystal sample suggests that some $\mathrm{MoO}_{3}$ volatility process may have occurred. However the degree of mass loss seems excessive relative to the limited amounts of Mo-containing scale phases observed overall.

In studies of NiAl-Mo in situ composites, analogous mass losses were established upon the formation of $\mathrm{NiMoO}_{4}$ scale phases [27]. Furthermore, bulk $\mathrm{NiMoO}_{4}$ samples were shown to decompose back to $\mathrm{NiO}$ due to $\mathrm{MoO}_{3}$ losses, which accelerated greatly for temperatures above $1100{ }^{\circ} \mathrm{C}$. Thus some of the $\mathrm{NiO}$ observed in the present study may be a daughter phase formed by $\mathrm{NiMoO}_{4}$ decomposition. They further point out that $\mathrm{NiMoO}_{4}$ is subject to phase changes at $250{ }^{\circ} \mathrm{C}$ on cooling, with corresponding volume changes that may increase scale spallation.

In a related study of $\mathrm{NiAl}-9 \mathrm{Mo}$ (atomic) directional eutectics, mass losses were observed in isothermal TGA tests, but only if the Mo rods were $\sim 0.1 \mu \mathrm{m}$ diameter [28]. Water vapor increased the loss, presumably by forming more volatile hydroxides, e.g., $\mathrm{MoO}_{2}(\mathrm{OH})_{2}$, by reacting with $\mathrm{MoO}_{3}$ vapor $[28,29]$. $\mathrm{Ni}(\mathrm{Mo}, \mathrm{W}) \mathrm{O}_{4}$ scales are occasionally observed for conventional superalloys [2,24]. That is the case for the Rene' 80 alloy tested here, having 4\% Mo. Other higher (Mo) commercial alloys would be Hastelloy X (9\% Mo), IN 625 (9\% Mo), and IN 617 (9\% Mo), all with high 20\% Cr and little or no Al, or B1900 (6\% Mo) and NX 188 (18\% Mo), both with 6\%-8\% Al. It can be seen from Table 2 that most of these commercial alloys populate the entire range of performance as the LDS alloys, from the very good to very poor oxidation resistance at $1100{ }^{\circ} \mathrm{C}$. Thus performance is not always pinned to Mo content. It should be noted that only the LDS and single crystal alloys in Table 2 were originally intended for use at temperatures as high as $1100{ }^{\circ} \mathrm{C}$; the other conventional alloys are only included to give a broader compositional perspective.

\subsection{Comparison of VIM Alloys to Oxidation of Low Density Single Crystals}

Finally, it should be pointed out that the subsequent single crystal versions performed considerably better than initial VIM compositions in the same $1100{ }^{\circ} \mathrm{C}$ cyclic test. Some were very similar to the $1100{ }^{\circ} \mathrm{C}$ test results for Rene' N5. The SX-VIM correlation can be seen in Figure 14 to be fairly divergent for low Cr alloys. For example, the single crystal (5555) alloy only lost $\sim 1 \mathrm{mg} / \mathrm{cm}^{2}$ at the end of the same test as compared to $-5 \mathrm{mg} / \mathrm{cm}^{2}$ for the VIM cast version. It is also important to point out that the high $\mathrm{Cr}$ single crystals all exhibited a low $+0.4 \mathrm{mg} / \mathrm{cm}^{2}$ weight gain and $\alpha-\mathrm{Al}_{2} \mathrm{O}_{3}$ as the prominent scale for the three $5 \mathrm{Cr}$ alloys [20]. The intent of the present paper is not to elaborate on the single crystal results. Yet, overall, the present oxidation tests of easily-obtained VIM specimens did allow successful projection of oxidation performance trends for the proposed alloying schemes in this compositional space. The explanation of why the single crystals performed better in oxidation than the polycrystalline VIM is not completely clear. It may be related to better homogenization and $\mathrm{Y}$ distribution in the single crystals or uncontrolled trace or tramp elements in the VIM versions. The lack of any grain boundary oxidation in the VIM specimens supports this screening approach. A recent study on (1101) single crystals has also shown that rough surface finish, i.e., machine grinding, promoted protective alumina scales at $817^{\circ} \mathrm{C}$, as opposed to fine polishing which resulted in fast growing external $\mathrm{NiO}$, with internal 
$\mathrm{Al}_{2} \mathrm{O}_{3}$-spinel scales [22]. Thus subtle factors are likely to be significant in controlling transient oxidation issues of this alloy.

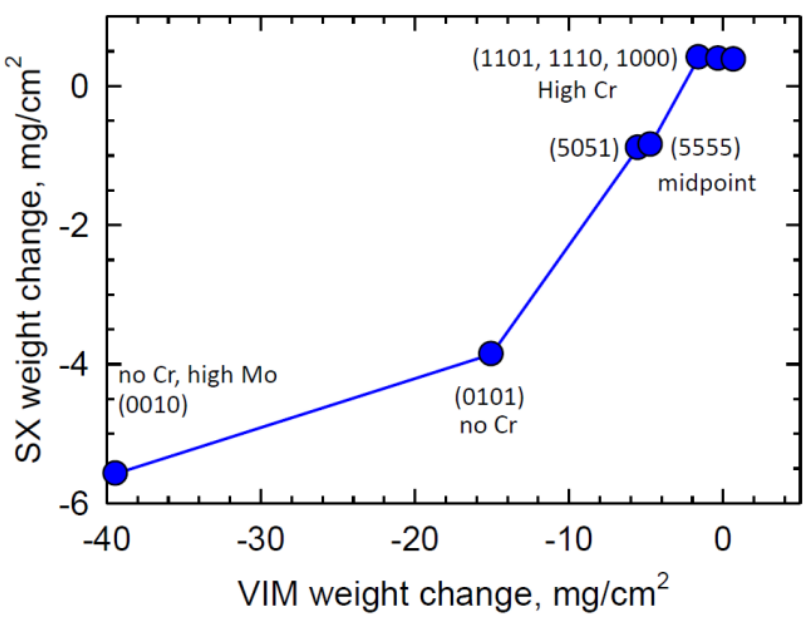

Figure 14. Correlation of improved single crystal oxidation for corresponding VIM results for the same $1100{ }^{\circ} \mathrm{C}, 200 \mathrm{~h}$ cyclic test.

In another compositional study of similar single crystal superalloys, decreased oxidation resistance was reported for just 1-2 wt. \% Mo [30]. However these were all at significantly lower 5.1\%-5.3\% $\mathrm{Al}$ and higher $4.4 \%-5.4 \% \mathrm{Re}$ and $5 \%-6 \% \mathrm{~W}$ contents. Interestingly, creep strength was also reported to be lower for the alloys with Mo. The results for this composition space seems to be at odds with the present findings at $6 \% \mathrm{Al}, 3 \% \mathrm{Re}$, and no $\mathrm{W}$.

\subsection{Broader Implications of Low Density Single Crystal Studies}

It should be stressed that the single crystal versions of the present LDS alloys achieved significant gains in creep behavior (Larsen-Miller Diagram) to warrant this study of high Mo superalloys [20,21]. A $40{ }^{\circ} \mathrm{C}$ advantage with a $1.5 \%$ density reduction was demonstrated for alloy (1101) over Rene' N5. Furthermore, density-normalized creep behavior was equivalent to those of 3rd generation single crystals. At $8.51 \mathrm{~g} / \mathrm{cm}^{2}$ this (1101) Ni-6Al-5Cr-10Co-7Mo-3Re-6.2Ta alloy exhibited density reductions of $2.2 \%, 3.8 \%$, and $4.9 \%$ compared to CMSX-4, SC180, and PWA1484, respectively. Given the intended substitution of Mo for $\mathrm{W}$, it is not especially different from the co-optimized composition arrived at from fundamental considerations, namely $\mathrm{Ni}-7 \mathrm{Al}-4 \mathrm{Cr}-10 \mathrm{Co}-3 \mathrm{~W}-3 \mathrm{Re}-5 \mathrm{Ta}$ and $\mathrm{Ni}-6 \mathrm{Al}-8 \mathrm{Cr}-10 \mathrm{Co}-3 \mathrm{Re}-8 \mathrm{~W}-8 \mathrm{Ta}$ [14]. Reasonable phase stability and burner rig hot corrosion resistance were also presented for the (1101) alloy, although severe hot corrosion was observed for some other high Mo alloys in this alloy group [20]. Only slight differences were produced by further minor variations on the (1101) target composition, with perhaps the best benefit accruing from the addition of $0.2 \%$ Hf. It was concluded that the Hf-modified (1101) alloy displayed an attractive balance of properties competitive with present commercial alloys. Since present single crystal airfoils are coated, the concept of using these reduced density alloys, and still benefitting from a protective coating to further minimize oxidation under extreme conditions, appears realistic. 


\section{Summary}

The cyclic oxidation resistance of various high Mo LDS superalloys were screened for potential turbine blade applications, with statistically designed variations in the $\mathrm{Cr}$, $\mathrm{Co}$, Mo, and Re levels. The base alloy was analogous to 2nd generation single crystal compositions, at 6.1Al, 6.2Ta, and $\sim 100 \mathrm{ppm} \mathrm{Y}$ and $\mathrm{C}$, but with no Ti, Nb, or $\mathrm{W}$. As expected, the use of low or no Cr overshadowed most other variations and produced fast growing, non-adherent outer, large grained $\mathrm{NiO}$ scales. These covered complex, layered $\mathrm{Ni}(\mathrm{Al}, \mathrm{Cr})_{2} \mathrm{O}_{4}$ and $\mathrm{Al}_{2} \mathrm{O}_{3}$ phases, with fine, dispersed $\mathrm{NiTa}_{2} \mathrm{O}_{6}$ particulates. $\mathrm{NiMoO}_{4}$, appearing feathery and only identified by XRD for the high Mo, low Cr LDS alloys (0111), was not widely present. It is suggested that some transitory Mo contribution to the scale may occur by evaporation of volatile $\mathrm{MoO}_{3}$, leaving a $\mathrm{NiO}$ reaction product. The high $\mathrm{Cr}(5 \%)$ alloys generally resulted in good oxidation resistance analogous to commercial 2nd generation single crystal alloys, though some $\mathrm{NiO}$ was still observed.

Multiple linear regression fitting produced an equation describing the final cyclic oxidation weight changes with a high positive coefficient $\mathrm{Cr}$ term, negative Co and Mo terms, and positive $\mathrm{Cr} \times \mathrm{Mo}$ and negative $\mathrm{Re} \times$ Mo interaction terms. Hence, high (12 wt. \%) Mo without Cr was associated with the worst performance, while the behavior was much improved if $5 \mathrm{wt}$. \% $\mathrm{Cr}$ was present. In single crystal form, quite attractive behavior was correspondingly retained even for a high $12 \%$ Mo alloy (1110). There appears to be a consistent oxidation benefit of single crystals compared to vacuum induction melting. This work is part of a broader study that has identified a co-optimized composition (1101), at $5 \mathrm{Cr}-10 \mathrm{Co}-7 \mathrm{Mo}-3 \mathrm{Re}$ (wt. \%), achieved up to a $40{ }^{\circ} \mathrm{C}$ creep advantage over Rene' N5 or up to a 5\% density advantage compared to PWA1484, with good phase stability and somewhat comparable hot corrosion resistance. Accordingly, the demonstration of acceptable cyclic oxidation resistance helps qualify these alloys for turbine blade applications.

\section{Acknowledgments}

This program was initiated and championed by M. Nathal. The XRD analyses of scale phases by R. Garlick and R. Rogers are gratefully acknowledged. Funding was provided by the NASA Fundamental Aeronautics Research and Advanced Air Transport Technology Project Office, Aeronautics Research Mission Directorate.

\section{Author Contributions}

James L. Smialek recommended oxidation resistant compositions, performed the oxidation tests, and analyzed the results; Anita Garg performed all SEM characterizations; Timothy P. Gabb led the mathematical D.O.E. matrix design for multi-parameter co-optimization and performed the statistical regression analysis of the data; Rebecca A. MacKay led the overall program that also addressed density, creep strength, and stablility and produced the alloys.

\section{Conflicts of Interest}

The authors declare no conflict of interest. 


\section{References}

1. Smialek, J.L.; Meier, G.H. High Temperature Oxidation. In Superalloys II; Sims, C.T., Stoloff, N.S., Hagel, W.C., Eds.; Wiley and Sons: New York, NY, USA, 1987; pp. 293-326.

2. Smialek, J.L.; Barrett, C.S.; Schaeffer, J.C. Design for Oxidation. In ASM Handbook, Volume 20: Design for Properties; ASM International: Materials Park, OH, USA, 1997; pp. 589-602.

3. Smialek, J.L.; Tubbs, B.K. Effect of sulfur removal on scale adhesion to PWA 1480. Metall. Mater. Trans. A 1995, 26, 427-435.

4. McVay, R.V.; Williams, P.; Meier, G.H.; Pettit, F.S.; Smialek, J.L. Oxidation of Low Sulfur Single Crystal Nickel-Base Superalloys. In Superalloys 1992; TMS: Warrendale, PA, USA, 1992; pp. 807-816.

5. Göbel, M.; Rahmel, A.; Schütze, M. The cyclic-oxidation behavior of several nickel-base single-crystal superalloys without and with coatings. Oxid. Met. 1994, 41, 271-300.

6. Smialek, J.L.; Jayne, D.T.; Schaeffer, J.C.; Murphy, W.H. Effects of hydrogen annealing, sulfur segregation and diffusion on the cyclic oxidation resistance of superalloys: A review. Thin Solid Films 1994, 253, 285-292.

7. Smialek, J.L.; Pint, B.A. Optimizing Scale Adhesion on Single Crystal Superalloys. Mater. Sci. Forum 2001, 369-372, 459-466.

8. Harris, K.; Wahl, J. Improved Single Crystal Superalloys. In Superalloys 2004; TMS: Warrendale, PA, USA, 2004; pp. 45-52.

9. Yuan, F.H.; Han, E.H.; Jo, C.Y.; Li, T.F.; Hu, Z.Q. The Effect of Crystallographic Orientation on the Oxidation Behavior of a Single-Crystal Nickel-base Superalloy. Oxid. Met. 2003, 60, 211-224.

10. Pieraggi, B.; Dabosi, F. High-temperature oxidation of a single crystal Ni-base superalloy. Mater. Corros. 1987, 38, 584-590.

11. Swadźba, R.; Swadźba, L.; Wiedermann, J.; Hetmańczyk, M.; Witala, B. Characterization of Alumina Scales Grown on a 2nd Generation Single Crystal Ni Superalloy During Isothermal Oxidation at 1050, 1100 and $1150{ }^{\circ}$ C. Oxid. Met. 2014, 82, 195-208.

12. Glatzel, U.; Thomas, M.; Silke, W.; Wortman, J. Nickel-Base Alloy for Producing Components Which Have Solidified in Single Crystal Form. U.S. Patent 20050254991 A1, 4 March 2005.

13. Wöllmer, S.; Mack, T.; Glatzel, U. Influence of tungsten and rhenium concentration on creep properties of a second generation superalloy. Mater. Sci. Eng. A 2001, 319-321, 792-795.

14. Reed, R.C.; Tao, T.; Warnken, N. Alloys-By-Design: Application to nickel-based single crystal superalloys. Acta Mater. 2009, 57, 5898-5913.

15. Sato, A.; Chiu, Y.L.; Reed, R.C. Oxidation of nickel-based single-crystal superalloys for industrial gas turbine applications. Acta Mater. 2011, 59, 225-240.

16. Reed, R.C.; Moverare, J.; Sato, A.; Karlsson, F.; Hasselqvist, M. A New Single Crystal Superalloy for Power Generation Applications. In Proceedings of the 12th International Symposium on Superalloys; Warrendale, PA, USA, 9-13 September 2012; pp. 197-204.

17. Adharapurapu, R.; Liu, L.; Pollock, T.M. University of Michigan, Ann Arbor, MI, USA. Unpublished research, 2012.

18. George, E.P.B.; Draper, N.R. Empirical Model-Building and Response Surfaces; Wiley and Sons: Hoboken, NJ, USA, 1987. 
19. Sall, J.; Lehman, A.; Stephens, M.; Creighton, L. JMP ${ }^{\circledR}$ Start Statistics: A Guide to Statistics and Data Analysis Using JMP ${ }^{\circledR}$, 5th ed.; SAS Institute, Inc.: Cary, NC, USA, 2012.

20. MacKay, R.A.; Gabb, T.P.; Smialek, J.L.; Nathal, M.V. Alloy Design Challenge : Development of Low Density Superalloys for Turbine Blade Applications; NASA: Cleveland, OH, USA, 2009; pp. 1-39.

21. MacKay, R.A.; Gabb, T.P.; Smialek, J.L.; Nathal, M.V. A New Approach of Designing Superalloys for Low Density. JOM 2010, 62, 48-54.

22. Sudbrack, C.K.; Beckett, D.L.; MacKay, R.A. Effect of Surface Preparation on the $815{ }^{\circ} \mathrm{C}$ Oxidation of Single-Crystal Nickel-Based Superalloys. JOM 2015, 67, 2589-2598.

23. MacKay, R.A.; Gabb, T.P.; Smialek, J.L.; Nathal, M.V. Low Density, High Creep Resistant Single Crystal Superalloy for Turbine Airfoils. U.S. Patent 7261783 B1, 28 August 2007.

24. Barrett, C.A. A High Temperature Cyclic Oxidation Data Base for Selected Materials Tested at NASA Glenn Research Center; NASA: Cleveland, OH, USA, 2003.

25. Giggins, C.S.; Pettit, F.S. Oxidation of Ni-Cr-Al Alloys between $1000{ }^{\circ} \mathrm{C}$ and $1200{ }^{\circ} \mathrm{C}$. J. Electrochem. Soc. 1971, 118, 1782-1790.

26. Barrett, C.A.; Lowell, C.E. Resistance of Ni-Cr-Al Alloys to Cyclic Oxidation at 1100 and $1200{ }^{\circ}$ C. Oxid. Met. 1977, 11, 199-223.

27. Ray, P.K.; Akinc, M.; Kramer, M.J. Formation of multilayered scale during the oxidation of NiAl-Mo alloy. Appl. Surf. Sci. 2014, 301, 107-111.

28. Brady, M.P.; Bei, H.; Meisner, R.A.; Lance, M.J.; Tortorelli, P.F. Effect of Mo dispersion size and water vapor on oxidation of two-phase directionally solidified NiAl-9Mo in situ composites. Scr. Mater. 2014, 80, 33-36.

29. Meschter, P.J.; Opila, E.J.; Jacobson, N.S. Water Vapor-Mediated Volatilization of High-Temperature Materials. Annu. Rev. Mater. Res. 2013, 43, 559-588.

30. Hashizume, R.; Yoshinari, A.; Kiyono, T.; Murata, Y.; Morinaga, M. Development of Ni-Based Single Crystal Superalloys for Power-Generation Gas Turbines. In Superalloys 2004; TMS: Warrendale, PA, USA, 2004; pp. 53-62.

(C) 2015 by the authors; licensee MDPI, Basel, Switzerland. This article is an open access article distributed under the terms and conditions of the Creative Commons Attribution license (http://creativecommons.org/licenses/by/4.0/). 